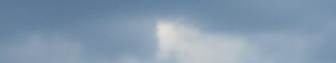

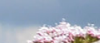

Pi .

$\operatorname{lot}^{4}$

1

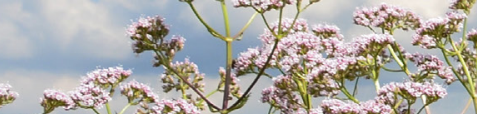

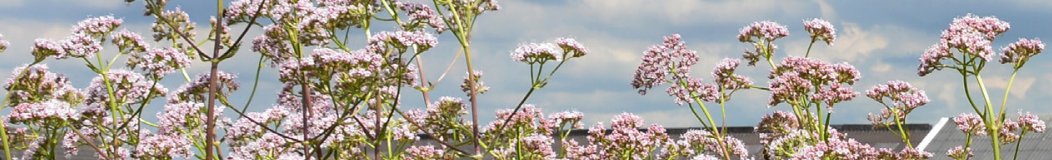

\section{Monitoring van functionele agrobiodiversiteit in de melkveehouderij: ontwikkeling van KPI's}




\section{Monitoring van functionele agrobiodiversiteit in de melkveehouderij: ontwikkeling van KPI's}

J. Zijlstra ${ }^{1}$, P. W. Blokland ${ }^{2}$, N. van Eekeren ${ }^{3}$, G. Migchels ${ }^{1}$, N. Polman ${ }^{2}$ en M. Bestman ${ }^{3}$

${ }^{1}$ Wageningen Livestock Research

2Wageningen Economic Research

${ }^{3}$ Louis Bolk Instituut

Dit onderzoek is uitgevoerd onder verantwoordelijkheid van Wageningen Livestock Research en het Louis Bolk Instituut, in opdracht van en gefinancierd door DZK/ZuiveINL en het Ministerie van Economische Zaken, binnen de Topsector Agri \& Food, roadmap Duurzame Veehouderij, Duurzame Zuivelketen, AF-15221, project Biodiversiteit' 
J. Zijlstra, P. W. Blokland, N. van Eekeren, G. Migchels, N. Polman en M. Bestman. Monitoring van functionele agrobiodiversiteit in de melkveehouderij: ontwikkeling van KPI's, Wageningen Livestock Research rapport 984, Louis Bolk Instituut rapport 2017-032 LbD.

Dit rapport is gratis te downloaden op http://dx.doi.org/10.18174/417021 of op www. wur.nl/livestock-research (onder Wageningen Livestock Research publicaties) of via www. louisbolk. nl (onder Publicaties).

\section{(c) 2017 Wageningen Livestock Research}

Postbus 338, 6700 AH Wageningen, T 03174839 53, E info.livestockresearch@wur.nl, www.wur.nl/livestock-research. Wageningen Livestock Research is onderdeel van Wageningen University \& Research.

\section{(C) 2017 Louis Bolk Instituut}

Kosterijland 3-5, 3981 AJ Bunnik, T 03435238 60, E info@louisbolk.nl, www.louisbolk.nl

Wageningen Livestock Research en Louis Bolk Instituut aanvaarden geen aansprakelijkheid voor eventuele schade voortvloeiend uit het gebruik van de resultaten van dit onderzoek of de toepassing van de adviezen.

Alle rechten voorbehouden. Niets uit deze uitgave mag worden vermenigvuldigd en/of openbaar gemaakt worden door middel van druk, fotokopie, microfilm of op welke wijze dan ook zonder voorafgaande toestemming van de uitgever of auteur.

De certificering volgens ISO 9001 door DNV onderstreept ons kwaliteitsniveau. Op als onze onderzoeksopdrachten zijn de Algemene Voorwaarden van de Animal Sciences Group van toepassing. Deze zijn gedeponeerd bij de Arrondissementsrechtbank Zwolle. 


\section{Inhoud}

Voorwoord

Begrippenlijst

Samenvatting

Summary

1

Inleiding $\quad 12$

$\begin{array}{lll}1.1 & \text { Aanleiding } & 12\end{array}$

1.2 Achtergrondinformatie 13

1.2.1 Doelen DZK 13

1.2.2 Aansluiting bij eerder onderzoek 13

1.2.3 Verschil tussen directe en indirecte indicatoren 13

1.2.4 Afbakening van het onderzoek in relatie tot andere initiatieven rond biodiversiteit op melkveebedrijven 13

$\begin{array}{lll}1.3 & \text { Doel onderzoek } & 14\end{array}$

2

$\begin{array}{ll}\text { Werkwijze } & 15\end{array}$

3

$\begin{array}{ll}\text { Resultaten } & 19\end{array}$

3.1 Stap 1: Lijst met indicatoren vanuit bestaande databases 19

3.2 Stap 2: Factoranalyse om samenhang, overlap en hoofdfactoren vast te stellen 19

3.3 Stap 3: Systeemanalyse: selectie van een beperkt aantal representatieve indicatoren $\quad 22$

3.3.1 Hoofdstructuur en hiërarchie tussen indicatoren 23

3.3.2 Onderlinge relaties tussen de geselecteerde indicatoren 23

3.3.3 Relatie van de geselecteerde indicatoren met drukfactoren $\quad 25$

3.3.4 Systeemanalyse: relaties tussen de geselecteerde indicatoren en functionele agrobiodiversiteit binnen de context van een melkveebedrijf 25

3.4 Stap 4: Toetsing indicatoren aan criteria voor gebruik in praktijk 29

4

Conclusies: KPI's voor monitoring

33

5

Discussie

34

$5.1 \quad$ Kanttekeningen en beperkingen onderzoek 34

5.2 Vervolgstappen naar monitoring $\quad 35$

6

Aanbevelingen voor vervolgonderzoek

37

Literatuur

Bijlage 1. Groslijst met indicatoren

Bijlage 2. Argumenten waarom indicatoren niet zijn meegenomen als KPI

Bijlage 3. Correlatiematrix per grondsoort 



\section{Voorwoord}

De Duurzame Zuivelketen (DZK) ziet het belang van behoud van biodiversiteit voor de melkveehouderij. Het natuurlijke en herkenbare karakter van het Nederlandse landschap en natuur is sterk verbonden met de beleving van Nederlandse zuivelproducten. De meerderheid van de Nederlandse melkveehouders draagt actief bij aan het behoud van biodiversiteit. Melkveebedrijven zijn afhankelijk van natuurlijke processen en zijn daardoor gebaat bij een rijke biodiversiteit. Dit wil DZK graag nadrukkelijker uitdragen. Naast het daadwerkelijk behoud en waar mogelijk herstel van de biodiversiteit is het van belang ook daadwerkelijk aan te tonen wat melkveehouders doen om dit te realiseren. Daarom is de ontwikkeling van een monitoringsystematiek voor biodiversiteit een belangrijk onderdeel van het Programma Biodiversiteit en Milieu binnen de Duurzame Zuivelketen.

Werken aan biodiversiteit op melkveebedrijven is zeker uitdagend. De ambitie om de bijdrage aan biodiversiteit meetbaar te maken is nieuw en het thema is abstract. In mijn werk voor FrieslandCampina en voor DZK heb ik ervaren dat het een enorme zoektocht is om te achterhalen wat alle verschillende partijen die bezig zijn met het thema verstaan onder de term biodiversiteit. Meer dan eens heb ik geconstateerd dat we dachten over de zelfde onderwerpen te praten omdat we de gelijke woorden gebruikten. Achteraf bleek dan echter vaak dat de verschillende gesprekspartners een geheel andere beleving hebben bij de gebruikte termen en woorden. Zolang er in de gezamenlijke zoektocht naar de invulling van het werken aan biodiversiteit ruimte is voor het verschil in belevingen en er de wil is om tot een gezamenlijke definitie te komen, is er perspectief op resultaat. Die vasthoudendheid is ook getoond door de groep mensen die heeft gewerkt aan een voorzet voor een monitoringsystematiek voor biodiversiteit en die uiteindelijk heeft geleid tot de inhoud in dit rapport. Dit resultaat biedt een basis om de biodiversiteitsmonitor verder te ontwikkelen.

Het onderzoek en de resultaten zoals beschreven in dit rapport leveren een belangrijke bijdrage aan een systematiek voor de melkveehouderij waarmee de invloed van individuele melkveehouders op biodiversiteit in beeld kan worden gebracht. Het unieke daaraan is dat de nadruk ligt op integraliteit van de onderwerpen die aan biodiversiteit gerelateerd zijn. Een natuurlijk evenwicht tussen kringlopen sluiten enerzijds en landgebruik anderzijds is essentieel voor het behoud van biodiversiteit. Achteraf gezien is het daarom logisch om het thema integraal te benaderen. Tegelijkertijd is dit wel een van de allergrootste uitdagingen geweest binnen het onderzoek. Zowel wat betreft kennis, onderlinge communicatie en de noodzaak tot een holistische benadering.

De resultaten uit het onderzoek zijn input voor de verdere ontwikkeling van de monitoringsystematiek voor biodiversiteit. Deze monitoringssystematiek zal de komende tijd verder fijngeslepen en doorontwikkeld worden. De resultaten kunnen daarom niet op zichzelf staand gezien worden. Ze zijn een stap in een uitgebreid proces om uiteindelijk tot een monitoringsystematiek voor biodiversiteit in de melkveehouderij te komen. Met dit rapport is wel de basis gelegd voor de indicatoren voor biodiversiteit en de integrale samenhang tussen indicatoren. Daardoor is het van waarde voor DZK.

Ik wil daarom alle betrokken onderzoekers van Wageningen Research en Louis Bolk Instituut bedanken voor hun inzet en het resultaat. Ook de financiers Ministerie van EZ en ZuivelNL verdienen een compliment voor het leveren van een belangrijke bijdrage aan het behoud van biodiversiteit op melkveebedrijven.

Guus van Laarhoven

Programmateamlid Biodiversiteit en Milieu

Duurzame Zuivelketen 


\section{Begrippenlijst}

\begin{tabular}{|c|c|}
\hline Begrip & Uitleg \\
\hline $\begin{array}{l}\text { Bedrijven I nformatie } \\
\text { Netwerk (BIN) }\end{array}$ & $\begin{array}{l}\text { Het Bedrijven-I nformatienet is een panel van } 1.500 \text { land- en } \\
\text { tuinbouwbedrijven, visserij- en particuliere bosbouwbedrijven, } \\
\text { waaronder ca. } 250 \text { gespecialiseerde melkveebedrijven. Door de opzet } \\
\text { en de keuze van bedrijven representeert dit panel (bijna) de hele } \\
\text { Nederlandse land- en tuinbouw. }\end{array}$ \\
\hline Drukfactor & $\begin{array}{l}\text { De Bie (2013) onderscheidde negen drukfactoren die biodiversiteit } \\
\text { kunnen beïnvloeden: energie (incl. CO2-emissie), landgebruik, } \\
\text { emissies naar lucht en water, landschap, bodemgebruik, } \\
\text { watergebruik, middelengebruik en licht \& geluid }\end{array}$ \\
\hline Effectindicator & $\begin{array}{l}\text { Indicator die het effect van de bedrijfsvoering op (een onderdeel van) } \\
\text { biodiversiteit weergeeft }\end{array}$ \\
\hline Factoranalyse & $\begin{array}{l}\text { Statistische techniek waarmee een lange lijst met onderling } \\
\text { verbonden indicatoren kan worden gereduceerd tot een kleiner aantal } \\
\text { achterliggende variabelen }\end{array}$ \\
\hline $\begin{array}{l}\text { Functionele } \\
\text { agrobiodiversiteit }\end{array}$ & $\begin{array}{l}\text { De kringloop op het bedrijf (bodem, gewas, koe en bedrijfssysteem) } \\
\text { als basis voor onder- en bovengrondse biodiversiteit, } \\
\text { watermanagement, koolstofvastlegging, nutriëntengebruik, etc. } \\
\text { (Erisman et al., 2014) }\end{array}$ \\
\hline Indicator & $\begin{array}{l}\text { Een indicator is een meetbaar fenomeen dat een signalerende functie } \\
\text { heeft en een aanwijzing is voor de kwantiteit of de kwaliteit van een } \\
\text { bedrijfsproces. Wijkt een indicator af van een afgesproken norm dan } \\
\text { is bijsturing mogelijk. }\end{array}$ \\
\hline Indirecte indicator & $\begin{array}{l}\text { Indicator die dient als plaatsvervanger van een niet eenvoudig } \\
\text { waarneembare of slechts tegen hoge kosten meetbare indicator }\end{array}$ \\
\hline Kringloopwijzer & $\begin{array}{l}\text { Overzicht met indicatoren over de verliezen van stikstof, fosfor en } \\
\text { koolstof op melkveebedrijven. Met deze indicatoren kunnen } \\
\text { agrarische ondernemers zowel hun management optimaliseren als } \\
\text { hun bedrijfsvoering verantwoorden naar overheden en ketenpartners }\end{array}$ \\
\hline $\begin{array}{l}\text { Kritische Prestatie Indicator } \\
\text { of Key Performance }\end{array}$ & $\begin{array}{l}\text { Een KPI is een indicator voor het monitoren en analyseren van } \\
\text { prestaties van ondernemingen. }\end{array}$ \\
\hline Indicator (beide KPI) & $\begin{array}{l}\text { (Het verschil tussen indicatoren en KPI's binnen dit onderzoek is dat } \\
\text { vanuit de beschikbare indicatoren een selecte groep van een beperkt } \\
\text { aantal indicatoren wordt gekozen die KPI worden genoemd. Samen } \\
\text { geven die een relatief volledig beeld van de beoordeling van de } \\
\text { impact die een melkveebedrijf heeft op de biodiversiteit.) }\end{array}$ \\
\hline Maatregelindicator & $\begin{array}{l}\text { Indicator die direct weergeeft dat er op een bedrijf een bepaalde } \\
\text { maatregel is uitgevoerd }\end{array}$ \\
\hline Milieubelastingspunten & $\begin{array}{l}\text { Systematiek waarbij in de vorm van een puntenscore het niveau van } \\
\text { milieubelasting van gewasbeschermingsmiddelen wordt aangegeven } \\
\text { (www.milieumeetlat.nl) }\end{array}$ \\
\hline Milieumeetlat & $\begin{array}{l}\text { Overzicht van de milieubelasting van alle in Nederland toegelaten } \\
\text { gewasbeschermingsmiddelen (www. milieumeetlat. } \mathrm{nl} \text { ) }\end{array}$ \\
\hline Variabele & Een variabele is een meetbaar kenmerk van een bedrijf \\
\hline
\end{tabular}




\section{Samenvatting}

\section{Inleiding}

De Duurzame Zuivelketen (DZK) heeft als ambitie om de biodiversiteit op alle melkveebedrijven in Nederland in kaart te brengen. Daarom wil ze daarvoor een monitoringssystematiek ontwikkelen. Om dat te realiseren heeft het DZK-programmateam Biodiversiteit en Milieu aan het consortium van Wageningen Research en Louis Bolk Instituut gevraagd om een advies te geven over welke Kritische Prestatie Indicatoren (KPI's) geschikt zouden zijn voor opname in een biodiversiteitsmonitor voor melkveebedrijven. Deze indicatoren zouden zowel een indruk moeten geven van de functionele agrobiodiversiteit op een bedrijf als van de drukfactoren die aangeven hoe een bedrijf biodiversiteit beïnvloedt. Onder functionele agrobiodiversiteit verstaan we de kringloop op het bedrijf: bodem, gewas, koe en bedrijfssysteem. De relevante drukfactoren voor biodiversiteit zijn: energie (incl. CO2emissie), landgebruik, emissies naar lucht en water, landschap, bodemgebruik, watergebruik, middelengebruik en licht $\&$ geluid.

\section{Doel}

Het doel van dit onderzoek was om een beperkt aantal KPI's te selecteren die samen een breed inzicht geven in de invloed die een melkveebedrijf heeft op biodiversiteit.

\section{Werkwijze en resultaten}

De aanpak van het onderzoek bestond uit 4 stappen die samen een trechterbenadering vormen. Er werd begonnen met een grote dataset met indicatoren en geëindigd met de beoogde selectie van een beperkt aantal KPI's.

Omdat er geen databases beschikbaar zijn waarin voor grote aantallen melkveebedrijven in Nederland gegevens zijn vastgelegd over de toestand van de biodiversiteit, is binnen dit onderzoek uitsluitend gebruik gemaakt van zogenoemde indirecte indicatoren. Dit betreft indicatoren waarvan op basis van literatuuronderzoek wordt verondersteld dat ze indicator zijn voor functionele agrobiodiversiteit en/of voor de impact die een melkveebedrijf heeft op biodiversiteit. Ze zijn afkomstig uit databases van Wageningen Economic Research. Deze databases bevatten met name landbouwkundige indicatoren, financieel-economische gegevens en duurzaamheidsindicatoren van bedrijven. Aan het eind van deze eerste stap was een database gevormd met daarin een groep van 98 indirecte indicatoren.

Tijdens de tweede stap is gewerkt aan het krijgen van meer inzicht in de verbanden tussen de indicatoren binnen de database. Met behulp van de statistische methode factoranalyse is onderzocht of en hoe de geselecteerde indicatoren gegroepeerd konden worden en of per groep indicatoren één representatieve factor benoemd kon worden. Uit deze analyse kwam naar voren dat de eerder genoemde 98 indicatoren zijn samen te vatten in 20 factoren. Deze informatie was nuttig voor het uitvoeren van de derde stap. Daarbij werd het aantal van 98 indicatoren gereduceerd door gebruik te maken van vier criteria. De te kiezen indicatoren moesten een relatie hebben met (1) functionele agrobiodiversiteit en/of (2) drukfactoren voor biodiversiteit. Daarnaast werden indicatoren gekozen die (3) ook representatief zijn voor andere - er mee gecorreleerde - indicatoren. Het laatste criterium (4) had betrekking op representativiteit van de gekozen indicatoren voor één of meerdere van de 20 factoren die in stap 2 waren onderkend. Op basis van de selectie in deze stap 3 bleef een lijst met 11 indicatoren over. In de vierde stap werden deze indicatoren vervolgens getoetst aan de volgende criteria die te maken hebben met de geschiktheid voor gebruik in de praktijk:

- Beschikbaarheid van basisgegevens in bestaande administraties.

- De noodzaak van aanvullende berekeningen.

- $\quad$ Externe borging van gegevens.

- De beschikbaarheid van een nulmeting.

$\mathrm{Na}$ deze toetsing bleven 10 indicatoren over die worden geadviseerd als KPI's voor biodiversiteit. 


\section{Conclusie: aanbevolen KPI's}

Voor implementatie op korte termijn worden de volgende KPI's aanbevolen voor het monitoren van functionele agrobiodiversiteit op melkveebedrijven:

1. \% grasland van de totale bedrijfsoppervlakte

2. $\%$ blijvend grasland van de totale bedrijfsoppervlakte

3. \% toepassing groenbemester na teelt voedergewas

4. N-bodemoverschot per ha

5. NH3-emissie per ha

6. \% voereiwit van eigen bedrijf

Op middellange termijn is de verwachting dat ook de volgende KPI voldoende geborgd kan worden om die ook mee te nemen in de monitoring:

7. Organische stofbalans bouwland/voedergewassen

Verder wordt aanbevolen om voor de langere termijn ook de volgende indicatoren te ontwikkelen:

8. Indicator voor grondbewerking bouwland/voedergewassen

9. Milieubelastingspunten per ha (impact van gewasbescherming op milieu)

10. Indicator voor gebruik van ontwormings- en vliegenbestrijdingsmiddelen

Voor deze laatste groep (indicator 7 tot en met 10) is het nodig extra gegevens te verzamelen, vast te leggen en te borgen omdat deze nog niet in de huidige beschikbare databases voorkomen.

\section{Aanbevelingen voor de verdere ontwikkeling van de monitoringssystematiek}

De hier gepresenteerde resultaten vormen bouwstenen voor een biodiversiteitsmonitor voor melkveebedrijven. Voor de verdere ontwikkeling van het werken aan de monitoring van functionele agrobiodiversiteit op melkveebedrijven, worden onderstaande vervolgstappen aanbevolen:

1. Zorg voor borging van de geadviseerde KPI's.

2. Zorg voor meer inzicht in relatie tussen KPI's en directe indicatoren voor biodiversiteit.

3. Toets de gevolgde werkwijze aan andere methoden voor monitoring van functionele agrobiodiversiteit op melkveebedrijven

4. Voeg indicatoren op het gebied van waterbeheer en watergebruik toe. 


\section{Summary}

\section{I ntroduction}

The Dutch organisation Sustainable Dairy Chain ${ }^{1}$ has the ambition to employ a monitoring system for biodiversity combined with concrete targets. To realize this, the organisation is planning to map the biodiversity of all dairy farms in the Netherlands. The organisation's Programme Team Biodiversity and Environment has asked a consortium of Wageningen Research and Louis Bolk Institute to give recommendations on Key Performance Indicators (KPIs) that are suitable to be included in a biodiversity monitoring system for dairy farms. These indicators should give an impression of both the functional agrobiodiversity on a dairy farm and the pressure factors that indicate how a farm affects biodiversity. Functional agrobiodiversity is defined as the cycle on the farm: soil, crop, cow and farming system. The relevant pressure factors for biodiversity are: energy (including $\mathrm{CO}_{2}$ emissions), land use, emissions to air and water, landscape, cultivation of soil, water use, use of biocides, light and noise.

\section{Goal}

This study aims to select a limited number of KPIs which together provide insight into the impact of a dairy farm on biodiversity.

\section{Method and results}

The approach of the study consists of four steps that form a funnel approach: starting with a large data set of indicators in the first step, and ending with a limited number of KPIs in the final step. Since there are no extensive Dutch databases available on the state of biodiversity on dairy farms, our research focuses on so-called indirect indicators. It is assumed that these indicators have a relationship with functional agro-biodiversity and/or the impact a dairy farm has on biodiversity. The indicators were derived from Wageningen Economic Research databases. They contain mainly agricultural performance indicators, financial and economic data and farm sustainability indicators. This first step resulted in a database, containing a group of 98 indirect indicators.

During the second step, we gained more insight into the relationships between the indirect indicators in the database. Using the statistical method factor analysis, we investigated whether and how the selected indicators could be grouped and whether every group could be represented by one particular factor.

The third step consists of a system analysis. In this phase, indicators that could qualify as a KPI for functional agro-biodiversity in dairy farms were selected. They were selected from the group of indicators collected during the first step, and on the basis of criteria and knowledge of the factors represented in the second step.

This analysis showed that the previously mentioned 98 indicators can be summarized in 20 factors. This information was useful for performing the third step. The number of 98 indicators was reduced by using four criteria. The indicators to be chosen had to be related to (1) functional agrobiodiversity and/or (2) pressure factors for biodiversity. In addition, indicators were chosen that (3) can also act as representative of other correlated indicators. The last criterion (4) concerned the representativeness of the chosen indicators for one or more of the 20 factors identified in step 2. Based on the selection in this step 3, a list of 11 indicators remained.

\footnotetext{
${ }^{1}$ http: //www.duurzamezuivelketen. nl/en
} 
In the fourth and final step, these indicators are evaluated taking into account the following criteria, that have to do with suitability for use in practice:

- Availability of basic data in existing databases.

- The need for additional calculations.

- External quality assurance of data.

- The availability of a baseline.

After this evaluation the 10 remaining indicators were identified as KPIs for biodiversity.

\section{Conclusion: recommended KPI s}

For implementation in the short run the following KPIs are recommended to monitor functional agricultural biodiversity:

1. Grassland as \% of the total surface of the farm

2. Permanent pasture as $\%$ of the total surface of the farm

3. \% cover crops after harvesting forage crops

4. $\mathrm{N}$ - surplus per ha

5. $\mathrm{NH}_{3}$ emissions per ha

6. \% feed protein grown on the farm

In the medium term, the following KPI is expected to be sufficiently secured to participate in the monitoring:

7. Organic matter balance of arable land / fodder crops

Furthermore, it is recommended to develop the following indicators for the long term:

8. Indicator about cultivation of arable land / fodder crops

9. Environmental impact points for biocide use per ha (environmental impact of crop protection)

10. Indicator for the use of preparations designed to expel parasitic worms and flies

For this last group of indicators (indicator 7 to 10), it is necessary to collect, record and secure additional data.

\section{Recommendations for further development of the monitoring system}

The results presented here are building blocks for biodiversity monitoring on dairy farms. For further development of monitoring functional agricultural biodiversity on farms, the next steps are recommended:

1. Improve the reliability of the recommended KPIs.

2. Investigate the relationships between KPIs and direct indicators of biodiversity.

3. Compare the procedure followed in this report with other methods used for monitoring functional agribiodiversity on dairy farms.

4. Add indicators in the field of water management and water use. 


\section{$1 \quad$ Inleiding}

\section{$1.1 \quad$ Aanleiding}

De Duurzame Zuivelketen (DZK) heeft als ambitie om de biodiversiteit op alle melkveebedrijven in Nederland in kaart te brengen. Daarom wil ze daarvoor een monitoringssystematiek ontwikkelen (DZK, 2016). Om dat te realiseren heeft het DZK-programmateam Biodiversiteit en Milieu aan het consortium van Wageningen Research en Louis Bolk Instituut gevraagd om een advies te geven welke Kritische Prestatie Indicatoren (KPI's) geschikt zijn om te worden opgenomen in de biodiversiteitsmonitor. Daarbij was het de ambitie om met een beperkt aantal meetbare KPI's inzicht te geven in de status met betrekking tot de functionele agrobiodiversiteit van een melkveebedrijf. Onder functionele agrobiodiversiteit verstaan we de kringloop op het bedrijf: bodem, gewas, koe en bedrijfsysteem. Verder gold als voorwaarde dat de KPI's gerelateerd zouden zijn aan drukfactoren (De Bie, 2013). De Bie onderscheidde negen drukfactoren: energie (incl. CO2-emissie), landgebruik, emissies naar lucht en water, landschap, bodemgebruik, watergebruik, middelengebruik en licht \& geluid. Deze thema's vertonen veel overlap met de thema's zoals die worden gebruikt door het Planbureau voor de Leefomgeving in de beschrijving van de milieudruk vanuit de landbouw (Van Grinsven et al., 2014). Ook was het uitgangspunt dat individuele melkveebedrijven integraal zouden moeten worden gemonitord voor wat betreft hun impact op de biodiversiteit in de omgeving. Onder integraal wordt hier verstaan: het streven naar een groep KPI's die zo veel mogelijk bekende aspecten van functionele agrobiodiversiteit en drukfactoren in beeld brengt en er tevens voor zorgt dat het werken met de combinatie van de geselecteerde groep KPI's niet leidt tot ongewenste neveneffecten voor andere duurzaamheidsaspecten. Figuur 1.1 is een schematische weergave van de relaties tussen functionele agrobiodiversiteit en drukfactoren, zowel op het melkveebedrijf als in de omgeving van dat bedrijf. Bij de keuzes voor KPI's moet naast de reeds genoemde factoren nadrukkelijk ook rekening worden gehouden met onderlinge relaties tussen indicatoren, relevantie binnen bestaand beleid, praktische haalbaarheid (beschikbaarheid indicatoren en borging) en de mogelijkheden voor melkveebedrijven om op de indicatoren te kunnen sturen.

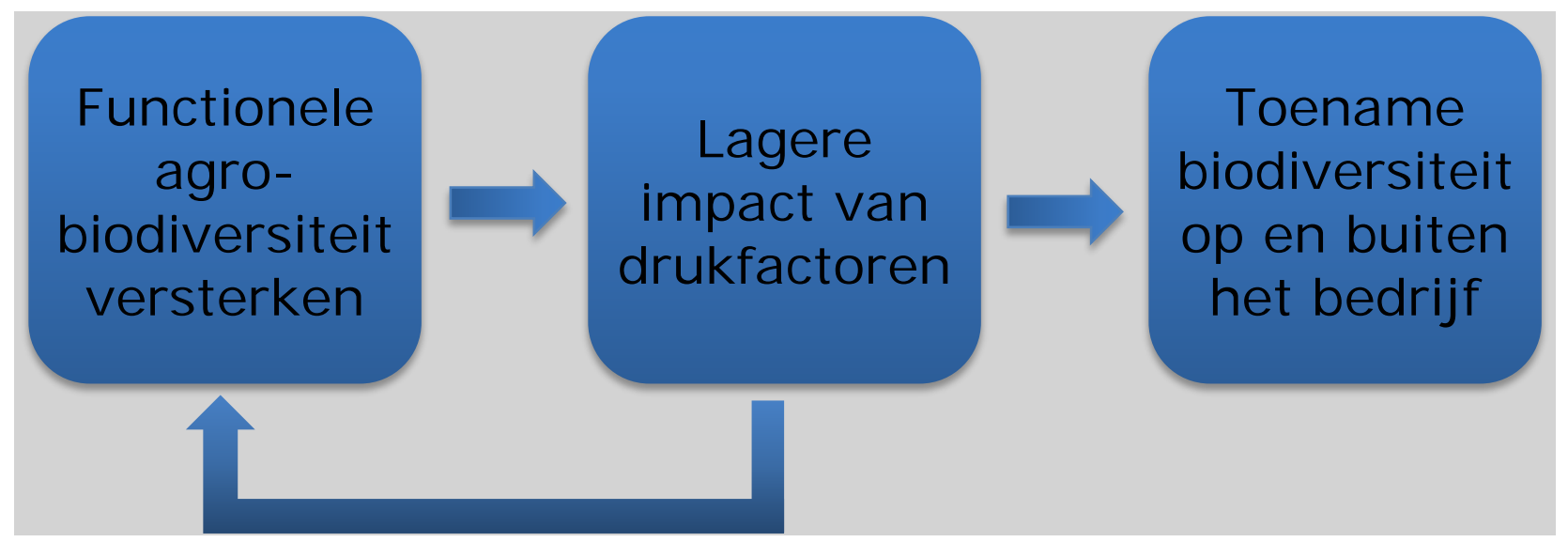

Figuur1.1. Relaties tussen functionele agrobiodiversiteit, drukfactoren en biodiversiteit (vrij naar Van Eekeren et al., 2015), zowel binnen het melkveebedrijf als met de omgeving van dat bedrijf. Door de toepassing van maatregelen op het gebied van het verbeteren van de functionele agrobiodiversiteit ontstaat er minder impact van drukfactoren waardoor er meer kansen komen voor de natuurlijke ontwikkeling van biodiversiteit binnen en buiten het bedrijf. Zo leiden een lagere bemesting en minder grondbewerkingen bijvoorbeeld tot een actiever bodemleven. Dat zorgt voor een actievere rol bij opname en afgifte van nutriënten waardoor er minder emissies zullen zijn naar bodem, water en lucht. Dat schept mogelijkheden voor een meer natuurlijke biodiverse ontwikkeling binnen en buiten het bedrijf. 


\subsection{Achtergrondinformatie}

\subsubsection{Doelen DZK}

Één van de doelen van DZK is behoud van biodiversiteit. Het streven is daarbij om op langere termijn de veerkracht van het biologische systeem dat bodem, gewas en dier omspant, te verbeteren. De concrete doelstelling voor biodiversiteit is: geen netto verlies van biodiversiteit (DZK, 2016). Dit houdt in dat de negatieve impact van de melkveehouderij op de biodiversiteit niet verder mag toenemen. Om inzicht te krijgen in de ontwikkeling hiervan, is in dit onderzoek gewerkt aan een monitoringssystematiek.

Tot nu toe heeft DZK voor de monitoring gewerkt met ondersteunende indicatoren die weergeven welke activiteiten melkveehouders ondernemen op het gebied van natuurbeheer (Reijs et al., 2016). Daarbij gaat het zowel om deelname aan overheidsregelingen waarbij melkveehouders subsidie ontvangen voor natuurbeheer, als om ongesubsidieerde vormen van natuurbeheer en om het lidmaatschap van agrarische natuurverenigingen die zich inzetten voor het stimuleren van natuur beheer door agrariërs.

\subsubsection{Aansluiting bij eerder onderzoek}

Dit onderzoek borduurt voort op het conceptueel kader zoals dat is omschreven in Erisman et al. (2014) en Van Eekeren et al. (2015). Daarin worden vier pijlers van biodiversiteit onderscheiden die onderling samenhangen:

1. Functionele agrobiodiversiteit: de kringloop op het bedrijf (bodem, gewas, koe en bedrijfssysteem) als basis voor onder- en bovengrondse biodiversiteit, watermanagement, koolstofvastlegging, nutriëntengebruik, etc. De intensiteit van een bedrijf en de grondgebondenheid bepalen in belangrijke mate of kringlopen gesloten worden op het bedrijf;

2. Landschappelijke diversiteit op het bedrijf: invloed van de fysieke omgeving (heggen, hagen, slootkanten, akkerranden, bosschages, waterpeil, etc.);

3. Specifieke soorten: beheer en management (maaien, bemestingssoort, techniek en tijdstip, etc.) voor behoud van specifieke soorten (o.a. weidevogels, grauwe kiekendief, korenwolf);

4. Brongebieden en verbindingszones (landschap): afstemming in een gebied (EHS, beheer, uitwisseling natte en droge gebieden, focus op regionale biodiversiteit, etc.).

Dit rapport is uitsluitend gericht op de selectie van KPI's voor pijler 1 in bovenstaande opsomming, de functionele agrobiodiversiteit. Er wordt geen aandacht wordt geschonken aan mogelijke KPI's voor natuur- en landschapsbeheer, brongebieden en verbindingszones. FrieslandCampina,

Wereldnatuurfonds en Rabobank werken binnen een ander project ("Business model voor biodiversiteit in de melkveehouderij"), dat momenteel (november 2016) nog in uitvoering is, aan de selectie van KPI's voor de pijlers 2 tot en met 4. Deze afbakening houdt in dat het integrale beeld op basis van $\mathrm{KPI}$ 's binnen dit rapport uitsluitend betrekking heeft op pijler 1 hierboven.

\subsubsection{Verschil tussen directe en indirecte indicatoren}

Omdat er geen databases beschikbaar zijn waarin voor grote aantallen melkveebedrijven in Nederland gegevens zijn vastgelegd over de toestand van de biodiversiteit, wordt binnen dit onderzoek uitsluitend gebruik gemaakt van zogenoemde indirecte indicatoren. Dit zijn indicatoren die door de onderzoekers zijn geselecteerd binnen beschikbare databases met indicatoren over Nederlandse melkveebedrijven en waarvan wordt verondersteld dat ze een relatie hebben met functionele agrobiodiversiteit en met de impact van drukfactoren op biodiversiteit.

Een directe indicator voor biodiversiteit zou bijvoorbeeld het aantal soorten kruiden in weilanden op het bedrijf kunnen zijn; maar deze informatie is niet voor grote aantallen bedrijven beschikbaar binnen databases. Het ontbreken van een directe indicator voor biodiversiteit maakt het onmogelijk om statistische verbanden te onderzoeken tussen biodiversiteit enerzijds en de indirecte indicatoren die in dit onderzoek worden gebruikt anderzijds. Het is dus ook niet mogelijk om op basis van de gedane statistische analyses uitspraken te doen over welke van de verzamelde indicatoren de beste maatstaven zijn voor functionele agrobiodiversiteit of biodiversiteit.

\subsubsection{Afbakening van het onderzoek in relatie tot andere initiatieven rond biodiversiteit op melkveebedrijven}

Het onderzoek waarvan de resultaten zijn beschreven in dit rapport was uitsluitend gericht op de selectie van indicatoren. Het is daarmee een eerste bouwsteen op weg naar een 
monitoringssystematiek die gericht is op het werken aan biodiversiteit op melkveebedrijven.

Belangrijke stappen die daarna nog gezet moeten worden om te komen tot een bedrijfsgerichte benadering voor melkveebedrijven, zijn: een beoordelingskader voor de indicatoren (systematiek voor het beoordelen van het niveau van de indicatoren, zo mogelijk met streefwaarden), een overzicht van maatregelen waarmee indicatoren beïnvloed kunnen worden en een pakket van stimulansen om te werken aan het verbeteren van de indicatoren.

Om meer draagvlak te krijgen voor het werken aan biodiversiteit op melkveebedrijven is het van belang om naast indirecte indicatoren ook te werken aan het meten en aantonen van de biodiversiteit in het veld. Dit is ook nodig om op langere termijn het verband tussen enerzijds indirecte indicatoren en anderzijds en de gemeten biodiversiteitstatus van een bedrijf meer inzichtelijk te kunnen maken.

De grote belangstelling - vanuit zowel de maatschappij als vanuit de zuivelsector - voor biodiversiteit op landbouwbedrijven leidt momenteel tot vele nieuwe initiatieven en zal waarschijnlijk ook nieuwe methoden opleveren om het effect van die initiatieven te monitoren. In internationaal verband wordt o.a. door International Dairy Federation (IDF), Food and Agricultural Organization (FAO) en Natural Capital Coalition gewerkt aan richtlijnen voor het werken aan biodiversiteit. Vele organisaties binnen en rond de melkveesector zullen hier de komende jaren mee aan de slag gaan.

Binnen Nederland is er ook een toenemende belangstelling voor beter bodembeheer dat een grote bijdrage kan leveren aan de toename van biodiversiteit. Daarnaast biedt de betrokkenheid van collectieven bij regionaal natuurbeheer nieuwe kansen om nadrukkelijker op individuele bedrijven te werken aan collectieve regionale doelen op het gebied van landschaps- en natuurbeheer.

De hierboven genoemde verdere ontwikkeling van een monitoringssystematiek, het meten en zichtbaar maken van biodiversiteit op melkveebedrijven, het toetsen aan internationale richtlijnen voor monitoring en het inspelen op de kansen die collectieven kunnen bieden bij het werken aan biodiversiteit vallen buiten het bestek van dit onderzoek.

\subsection{Doel onderzoek}

Het doel van dit onderzoek was om een aantal KPI's te selecteren die samen een breed inzicht geven in de invloed die een melkveebedrijf heeft op biodiversiteit.

Dit rapport bevat een advies aan DZK over KPI's die geschikt zijn om te worden opgenomen in de biodiversiteitsmonitor en beschrijft de werkwijze die is gehanteerd om tot dit advies te komen. 


\section{$2 \quad$ Werkwijze}

De aanpak van het onderzoek bestond uit 4 stappen die samen een trechterbenadering vormen. Deze is schematisch weergegeven in figuur 2.1. Er wordt begonnen met een grote set met indicatoren en geëindigd met de beoogde set van een beperkt aantal KPI's.

\section{Stap 1: Lijst maken van indicatoren uit bestaande databases, die een relatie met functionele agrobiodiversiteit hebben}

Omdat er geen databases beschikbaar zijn waarin voor grote aantallen melkveebedrijven in Nederland gegevens zijn vastgelegd over de toestand van de biodiversiteit, is binnen dit onderzoek uitsluitend gebruik gemaakt van zogenoemde indirecte indicatoren (zie ook 1.2.3). De eerste stap was een selectie van indicatoren die beschikbaar zijn in bestaande databases door alle daarin voorkomende indicatoren te beoordelen op hun veronderstelde impact op functionele agrobiodiversiteit en/of drukfactoren. Er is gebruik gemaakt van de volgende databases van Wageningen Economic Research:

- $\quad$ Bedrijveninformatienet (BIN);

- Landelijk Meetnet Mest en Mineralen (LMM), onderdeel van het BIN;

- Kringloopwijzer (KLW): gegevens ontleend aan Kringloopwijzer zoals die worden vastgelegd in het BIN;

- $\quad$ Regelingsdata, waarin o.a. deelname aan en gegevens over de Regeling Agrarisch Natuurbeheer (nummer regeling en areaal) zijn vastgelegd.

Deze databases bevatten met name landbouwkundige indicatoren, financieel-economische gegevens en duurzaamheidsindicatoren van bedrijven. Voor de selectie van indicatoren is ook gebruik gemaakt van de geadviseerde indicatoren uit Van Eekeren et al. (2015) en Zijlstra et al. (2015). Voor wat betreft indicatoren m.b.t. grondoppervlak, bodem, gewassen, milieu, natuurbeheer en economie is ook gebruik gemaakt van Polman et al. (2015) en Sanders en Westerink (2015). Tenslotte zijn beschikbare indicatoren m.b.t. drukfactoren (Zijlstra et al., 2015; van Eekeren et al.2015) en intensiteit van grondgebruik opgenomen in de lijst.

\section{Stap 2: Factoranalyse om samenhang, overlap en hoofdfactoren vast te stellen: indicatoren samenvatten in beperkter aantal factoren}

Tijdens de tweede stap is gewerkt aan het krijgen van meer inzicht in de verbanden tussen de indicatoren binnen de dataset die tijdens de eerste stap is ontstaan.

Daarvoor is gebruik gemaakt van de gegevens van ca. 250 bedrijven per jaar waarvan in de periode 2012 tot en met 2014 de geselecteerde indicatoren beschikbaar waren. Voorwaarde voor opname van bedrijfsgegevens was dat alle bedrijven voor alle variabelen resultaten hadden in de dataset. Door deze beperkende voorwaarde waren 406 volledige sets met jaargegevens beschikbaar vanuit de groep van ca. 250 bedrijven per jaar.

Met behulp van de statistische methode factoranalyse is onderzocht of en hoe de geselecteerde indicatoren gegroepeerd konden worden en of per groep indicatoren één representatieve factor benoemd kon worden. Factoranalyse is een multivariate techniek waarmee een lange lijst met indicatoren kan worden gereduceerd tot een kleiner aantal achterliggende variabelen (J ongeneel et al., 2008). Deze niet geobserveerde, achterliggende variabelen worden factoren genoemd. De gebruiker kan hier een term aan geven die de samenhangende achterliggende groep van de oorspronkelijke indicatoren samenvat. Ook zijn correlaties tussen een groot aantal indicatoren berekend voor het verantwoord reduceren van het aantal indicatoren. De factoranalyse resulteerde in een gereduceerd aantal factoren.

Bij een goede factoroplossing bepaalt een relatief klein aantal factoren samen een groot deel van de variatie in de oorspronkelijke variabelen. De factor die als eerste uit de analyse komt, verklaart het grootste deel van die variatie. De factor die er als tweede uitkomt, vertoont een minimale correlatie met de eerste en neemt het op één na grootste deel van de totale variatie voor zijn rekening. Voor de erop volgende factoren geldt het zelfde, maar naarmate er meer factoren worden benoemd, geldt over het algemeen dat de correlatie met de factoren met een hogere rangorde meestal (iets) toeneemt, terwijl het extra verklaarde deel van de totale variatie afneemt.

De factoranalyse is allereerst gedaan voor de totale dataset van 406 waarnemingen die in het onderzoek waren betrokken. Daarnaast hebben we ook nog analyses uitgevoerd op verschillende 
selecties van de dataset: intensieve bedrijven, extensieve bedrijven, bedrijven met natuurbeheer en bedrijven zonder natuurbeheer. Deze zijn apart geanalyseerd om na te gaan of binnen die groepen mogelijk andere factoren zouden worden gevonden. Daarbij was de achterliggende veronderstelling dat binnen de groepen extensieve bedrijven en bedrijven met natuurbeheer de gemiddelde biodiversiteit mogelijk hoger zou zijn dan binnen de intensieve bedrijven en bedrijven zonder natuurbeheer. Daardoor zouden ook de gevonden factoren en de verbanden tussen de indicatoren mogelijk kunnen afwijken. Het belangrijkste doel van de aanvullende data-analyse is om een indruk te krijgen van de stabiliteit van de gevonden factoren: wanner ze per dataset verschillen, zijn ze minder stabiel.

Hierbij moet nogmaals worden opgemerkt dat de werkelijke biodiversiteit op de bedrijven niet gemeten is en dus ook niet als variabele in de datasets voorkomt.

\section{Stap 3: Systeemanalyse: selectie van een beperkt aantal representatieve indicatoren}

De derde stap bestond uit een systeemanalyse waarbij vanuit de in stap 1 geselecteerde indicatoren mede op basis van de kennis over de factoren uit stap 2 - indicatoren zijn geselecteerd die mogelijk in aanmerking zouden kunnen komen als KPI voor biodiversiteit op melkveebedrijven.

Bij die selectie zijn de volgende criteria gehanteerd (in volgorde van belangrijkheid):

1. Relatie met functionele agrobiodiversiteit

De hoeveelheid organische stof in de bodem en het bodemleven zijn de sleutelfactoren voor functionele agrobiodiversiteit. Deze combinatie zorgt voor de natuurlijke activiteit in de bodem die gericht is op het leveren van gewasopbrengsten. Bij de keuze van indicatoren moeten de relatie met de opbouw en de instandhouding van organische stof en de actieve rol die het bodemleven daarbij kan spelen duidelijk in beeld komen.

2. Relatie met drukfactoren

De te kiezen indicatoren moeten een relatie hebben met emissies van melkveebedrijven naar hun directe omgeving. Daarbij gaat het met name om N, P, NH3, broeikasgassen,

gewasbeschermingsmiddelen en ontwormings- en vliegenbestrijdingsmiddelen als de belangrijkste emissiefactoren.

3. Beperkt houden van het aantal indicatoren door rekening te houden met onderlinge relaties

Eén van de wensen van de opdrachtgever was dat het aantal KPI's beperkt zou blijven tot ca. vijf. Dit kan door rekening te houden met verbanden tussen diverse indicatoren. Wanneer ze onderling sterk gecorreleerd zijn, worden bij voorkeur indicatoren gekozen als KPI die representatief zijn voor één of meer andere - gecorreleerde - relevante indicatoren.

Daarbij wordt met name rekening gehouden met correlaties die groter zijn dan 0,3 of kleiner dan $-0,3$.

4. Relatie met de factoren uit factoranalyse

De uitgevoerde factoranalyse biedt een beeld van de belangrijkste factoren die uit de dataset naar voren komen. De te kiezen indicatoren zouden bij voorkeur ook een beeld van deze factoren (die in dit verband ook gezien kunnen worden als thema's die een dominante rol spelen binnen de database uit stap 2) moeten kunnen schetsen.

De eerste drie criteria zijn door de onderzoekers afgeleid uit de doelen van het onderzoek. Het vierde criterium is er aan toegevoegd om de resultaten van de factoranalyse te benutten. 


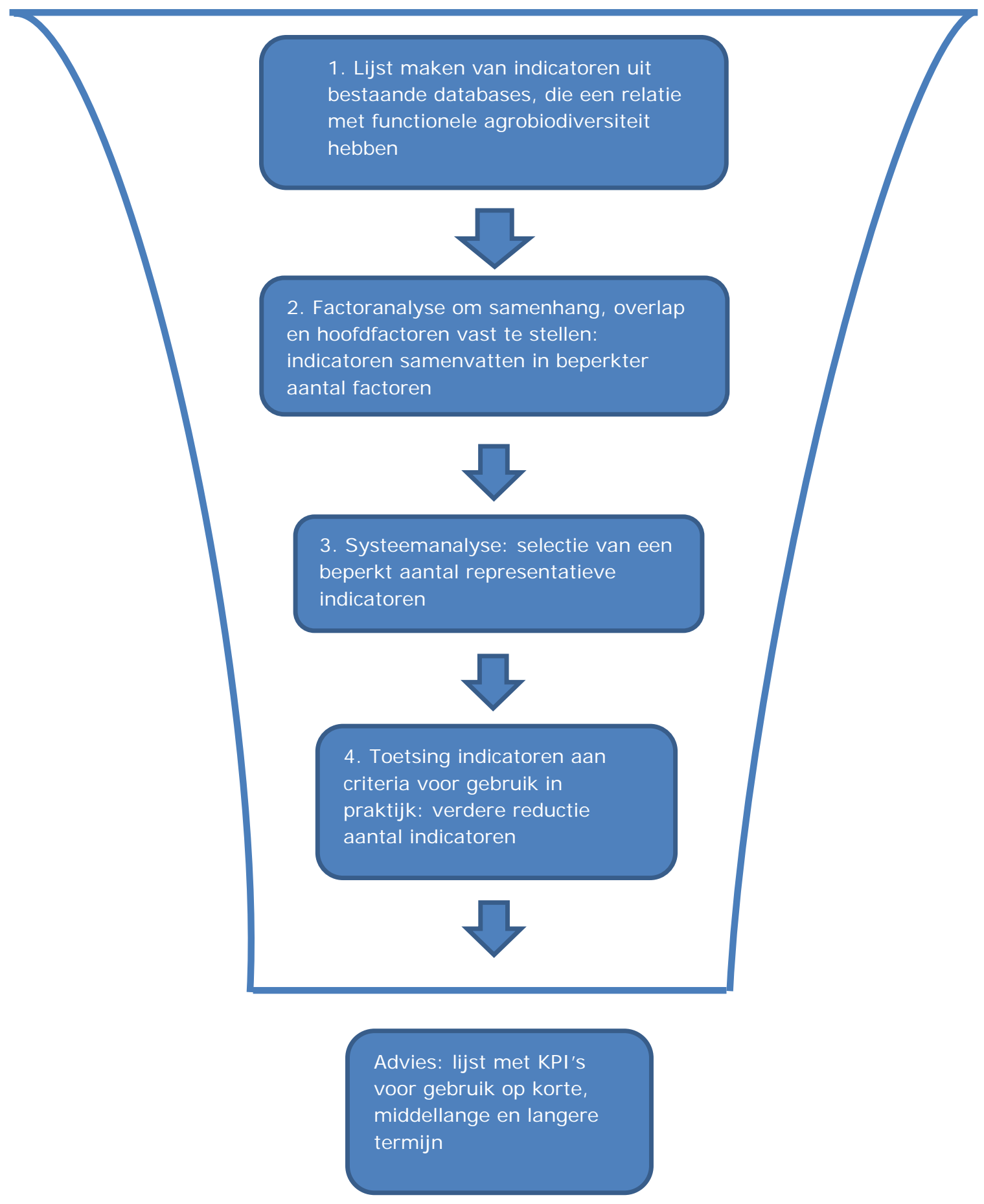

Figuur 2.1 Schematische weergave van de aanpak van het onderzoek. 


\section{Stap 4: Toetsing indicatoren aan criteria voor gebruik in praktijk: verdere reductie aantal indicatoren}

In de vierde stap werden de verkregen geselecteerde indicatoren uit stap 3 getoetst aan onderstaande criteria. Deze criteria zijn gedeeltelijk afgeleid uit Van Eekeren et al. (2015) en aangepast met het doel om een toetsing op bruikbaarheid uit te voeren. Dit leverde de volgende vier criteria op:

1. Zijn de basisgegevens voor het berekenen van de indicator beschikbaar in bestaande administraties?

Hierbij is gekeken of deze data momenteel reeds ergens in de keten digitaal worden vastgelegd.

Dit kan zijn op het melkveebedrijf of in een externe database waarin gegevens van melkveebedrijven worden opgeslagen.

2. Zijn aanvullende berekeningen noodzakelijk? Hierbij is het de vraag of er vanuit beschikbare basisgegeven extra berekeningen gemaakt moeten worden om de betreffende indicator te berekenen.

3. Zijn de verzamelde gegevens geborgd via een onafhankelijke externe borging? Hierbij is het de vraag of de beschikbare basis gegevens voor een indicator momenteel reeds extern geborgd zijn. Dat wil zeggen dat de gegevens worden vastgelegd via een proces dat objectieve en juiste data oplevert. De borging gebeurt door een organisatie die er op toe ziet dat de gegevens aansluiten bij de werkelijke situatie op het bedrijf. Borging is een belangrijk onderdeel van het proces omdat het monitoringssysteem ook bruikbaar zou moeten zijn voor uitbetaling op basis van hoe bedrijven scoren op de indicatoren. Mogelijk zullen ook andere partijen (overheden, banken, collectieven van agrarische natuurorganisaties, enz.) gebruik willen maken van de indicatoren en ook dan is borging essentieel.

4. Is er een nulmeting beschikbaar?

Hierbij is het de vraag of er op basis van gegevens over de betreffende indicator in bestaande databases een nulmeting beschikbaar is. De nulmeting levert informatie op over het niveau van de indicator op het moment waarop de monitoring start.

Het eindresultaat van deze toetsing is een groep indicatoren die de status van geadviseerde KPI krijgen. De zo verkregen KPI's worden ingedeeld in drie groepen:

a. Beschikbaar op korte termijn: binnen 2 jaar bruikbaar op basis van beschikbare gegevens

b. Beschikbaar op middellange termijn: binnen 4 jaar bruikbaar na verbetering van de borging van de betreffende indicatoren

c. Beschikbaar op langere termijn: uitsluitend beschikbaar wanneer aanvullende gegevens worden verzameld en geborgd. Er wordt van uit gegaan dat het enkele jaren zal vergen om deze nieuwe indicatoren te registreren via een geborgd proces. 


\subsection{Stap 1: Lijst met indicatoren vanuit bestaande databases}

De selectie van indicatoren die beschikbaar waren in de bestaande databases leverde 98 indicatoren op. De volledige lijst met indicatoren is opgenomen in bijlage 1 van dit rapport.

\subsection{Stap 2: Factoranalyse om samenhang, overlap en hoofdfactoren vast te stellen}

In tabel 3.1 staan de resultaten van de factoranalyses voor alle bedrijven samen en voor de vier verschillende selecties van de dataset:

1. Alle bedrijven in het onderzoek

2. Alle intensieve bedrijven

3. Alle extensieve bedrijven

4. Alle bedrijven met natuurbeheer

5. Alle bedrijven zonder natuurbeheer.

Bij de presentatie van de resultaten van de factoranalyses zijn voor elke selectie alleen de eerste 8 factoren weergegeven. In tabel 3.1 betreft dit in totaal 20 verschillende factoren. Factoren die in meerdere sets voorkomen zijn benadrukt door ze een zelfde kleur te geven.

Aan alle factoren is door de onderzoekers een term toegekend, die het cluster met indicatoren typeert dat onder die factor is weergegeven binnen de uitslag van het statistisch pakket, nl: grootte $(5 x)$, intensiteit $(3 x)$, maaipercentage $(2 x)$, grondsoort veen $(3 x)$, opstallen $(1 x)$, eigen voer $(5 x)$, beregening $(2 x)$, \% snijmais $(3 x)$, gangbaar/biologisch $(2 x)$, gewasbescherming $(2 x)$, graslandopbrengst eigen voer $(1 x)$, scheuren $(1 x)$, gangbaar/veen $(1 x)$, snijmaisopbrengst $(2 x)$, maisteelt gewasbescherming $(2 x)$, ruw eiwit $(1 x)$, natuurbeheer $(1 x)$, deelname KLW $(1 x)$, water $(1 x)$, snijmaisteelt $(1 x)$. Hoe vaker een factor naar voren komt, des te bepalender is deze factor voor het verklaren van de variatie binnen de groep van de 98 verzamelde indicatoren.

In de laatste twee kolommen van tabel 3.1 staan statistische parameters weergegeven die de zeggingskracht van de factoranalyse (KMO-test) en de betrouwbaarheid (significantie) ervan weergeven. Een relatief hoge waarde van de KMO-test en een lage kans in de kolom significantie geven aan dat resultaten van een factoranalyse betrouwbaar zijn. Met andere woorden, de aangegeven acht factoren verklaren een groot deel van de totale variantie in de dataset.

De verschillen in uitkomsten tussen de verschillende selecties zijn vrij gering. Bij de analyse van de variabelen is de bedrijfsgrootte de belangrijkste factor. Dit is te herleiden naar het feit dat de indicatoren zijn uitgedrukt in absolute eenheden. Deze worden sterk beïnvloed door de bedrijfsgrootte. Omdat ons uitgangspunt is dat biodiversiteit niet afhankelijk is bedrijfsgrootte, wordt deze factor niet meegenomen in de selectieprocedure voor KPI's.

Op basis van de resultaten van de factoranalyse, kunnen we het volgende concluderen:

1. Het \% eigen voer komt in alle vijf selecties naar voren met een hoge factorscore. Deze indicator is ook sterk gecorreleerd met intensiteit (zie bijlage3).

2. Andere dominante factoren zijn: \% snijmaïs, intensiteit, grondsoort veen en milieubelastingspunten als gevolg van het gebruik van gewasbeschermingsmiddelen.

3. De factor \% snijmaïs vertoont veel overeenkomst met het watergebruik (via beregening), het gebruik van gewasbeschermingsmiddelen en met het scheuren van grasland. Dit zijn allemaal factoren die verbonden zijn aan bedrijven met maïs in het bouwplan.

4. Alleen binnen selectie 1 (alle bedrijven in tabel 3.1) komt een factor naar voren die duidelijk gerelateerd kan worden aan de aanwezigheid van de tak natuurbeheer op melkveebedrijven. Waarschijnlijk ontbreekt deze factor binnen de andere datasets omdat de bedrijven met en zonder natuurbeheer daarin meer gescheiden zijn: bedrijven met natuurbeheer zitten waarschijnlijk 
vooral in de datasets 'Extensief' en 'Met natuurbeheer' en 'Zonder natuurbeheer' komen waarschijnlijk vooral voor in de beide andere subsets.

5. Grondsoort veen komt in twee selecties naar voren als aparte factor. Dit kan waarschijnlijk verklaard worden uit het feit dat de geselecteerde 98 indicatoren op bedrijven met veen sterker afwijken van het gemiddelde dan bedrijven op zand en klei. De veronderstelling is dat dit vooral te maken heeft met de afwijkende rol van de bodem (o.a. op punten als mineralisatie en N2Oemissie), de lagere intensiteit en een laag aandeel snijmaïs in het bouwplan op melkveebedrijven op veengrond.

6. Of een bedrijf gangbaar of biologisch is, heeft ook invloed op bepaalde variabelen. Onderscheidend zijn bijvoorbeeld het percentage drijfmest, benutting van de mest, kunstmestgebruik, bodemoverschot, weidegang en grondsoort.

Alle punten die hierboven zijn genoemd, worden gewoonlijk gezien als cruciale elementen om het bedrijfssysteem op een melkveebedrijf te omschrijven: intensiteit (gekoppeld aan \% eigen voer, maaipercentage), grondsoort, wel of geen snijmaïs (gekoppeld aan gewasbescherming, beregening en scheuren van grasland), wel of geen natuurbeheer, gangbaar of biologisch. De conclusie uit de resultaten van de factoranalyse is: een beperkt aantal (20) factoren typeert de relevante bedrijfskenmerken. 
Tabel 3.1. Overzicht van de resultaten van de factoranalyse voor 98 variabelen voor vijf verschillende indelingen van de dataset.

\begin{tabular}{|c|c|c|c|c|c|c|c|c|c|c|c|}
\hline & & & & \multicolumn{8}{|c|}{ Factor } \\
\hline & 1 & 2 & 3 & 4 & 5 & 6 & 7 & 8 & $\begin{array}{l}\text { Aantal } \\
\text { waarne- } \\
\text { mingen }^{1}\end{array}$ & KMO test ${ }^{2}$ & $\begin{array}{c}\text { Significan- } \\
\text { tie }^{3}\end{array}$ \\
\hline Alle bedrijven & grootte & intensiteit & eigen voer & beregening & $\begin{array}{l}\text { gangbaar/ } \\
\text { biologisch }\end{array}$ & $\begin{array}{l}\text { grondsoort } \\
\text { veen }\end{array}$ & $\begin{array}{c}\text { maïsteelt/ } \\
\text { gewasbe- } \\
\text { scherming }\end{array}$ & $\begin{array}{l}\text { natuur- } \\
\text { beheer }\end{array}$ & 406 & 0.739 & 0.000 \\
\hline Intensief & grootte & $\begin{array}{c}\text { maai- } \\
\text { percentage }\end{array}$ & beregening & eigen voer & \% snijmaïs & scheuren & $\begin{array}{l}\text { deelname } \\
\text { Kringloop- } \\
\text { wijzer }\end{array}$ & ruw eiwit & 194 & 0.643 & 0.000 \\
\hline Extensief & grootte & $\begin{array}{c}\text { maai- } \\
\text { percentage }\end{array}$ & eigen voer & $\begin{array}{c}\text { gangbaar/ } \\
\text { veen }\end{array}$ & \% snijmaïs & $\begin{array}{l}\text { gewasbe- } \\
\text { scherming }\end{array}$ & intensiteit & $\begin{array}{l}\text { snijmaïs } \\
\text { opbrengst }\end{array}$ & 212 & 0.652 & 0.000 \\
\hline $\begin{array}{l}\text { Met } \\
\text { natuurbeheer }\end{array}$ & grootte & $\begin{array}{c}\text { grondsoort } \\
\text { veen }\end{array}$ & eigen voer & $\begin{array}{l}\text { gangbaar/ } \\
\text { biologisch }\end{array}$ & $\begin{array}{l}\text { grasland- } \\
\text { opbrengst } \\
\text { eigen voer }\end{array}$ & $\begin{array}{l}\text { snijmaïs } \\
\text { opbrengst }\end{array}$ & $\begin{array}{c}\text { maïsteelt/ } \\
\text { gewasbe- } \\
\text { scherming }\end{array}$ & water & 164 & 0.652 & 0.000 \\
\hline $\begin{array}{l}\text { Zonder } \\
\text { natuurbeheer }\end{array}$ & grootte & opstallen & intensiteit & eigen voer & $\begin{array}{l}\text { gewasbe- } \\
\text { scherming }\end{array}$ & $\%$ snijmaïs & $\begin{array}{l}\text { snijmaïs- } \\
\text { teelt }\end{array}$ & $\begin{array}{l}\text { grondsoort } \\
\text { veen }\end{array}$ & 242 & 0.694 & 0.000 \\
\hline
\end{tabular}

1 Dit aantal waarnemingen betreft het aantal volledige sets met geselecteerde indicatoren vanuit de groep van 250 bedrijven waarvoor van drie jaargangen ( 2012 tot en met 2014) met bedrijfsresultaten beschikbaar waren.

2 De Kaiser-Meyer-Olkin (KMO) Test is een maatstaf voor de geschiktheid van de data om een factoranalyse uit te voeren. De test meet de geschiktheid van elke variabele in het model en ook die voor het complete model. Het resultaat is een maat voor de verhouding van de variantie tussen variabelen die mogelijk een gezamenlijke variantie hebben. Een minimum waarde van 0.5 wordt vaak gehanteerd om aan te geven dat de data geschikt zijn voor factor analyse.

3 De Bartlett's test op significantie toetst de nulhypothese "dat er geen correlatie is tussen de variabelen". De lage waarden geven aan dat de data geschikt zijn voor factoranalyse.

4 Gewasbescherming is binnen dit onderzoek uitgedrukt in milieubelastingspunten. 


\subsection{Stap 3: Systeemanalyse: selectie van een beperkt aantal representatieve indicatoren}

In tabel 3.3 staan de indicatoren die het resultaat zijn van de systeemanalyse uit stap 3. In de rechterkolom staat een korte toelichting op het belang van de betreffende indicator voor de functionele agrobiodiversiteit en/of de impact op biodiversiteit. In 3.3.4. wordt nog dieper ingegaan op het belang van de indicatoren voor de functionele agrobiodiversiteit.

Tabel 3.2. Geselecteerde indicatoren op basis van de systeemanalyse

\begin{tabular}{|c|c|c|}
\hline \multicolumn{2}{|c|}{ Indicatoren } & \multirow{2}{*}{$\begin{array}{l}\text { Directe indicator voor organische stof. Organische } \\
\text { stof is een levensvoorwaarde voor } \\
\text { bodemorganismen en daarmee een zeer } \\
\text { belangrijke indicator voor de diversiteit aan } \\
\text { levensvormen in de bodem. }\end{array}$} \\
\hline & $\%$ organische stof in bodem & \\
\hline b. & $\%$ grasland van de totale bedrijfsoppervlakte & $\begin{array}{l}\text { Belangrijke indicator voor de opbouw en het } \\
\text { behoud van organische stof. }\end{array}$ \\
\hline C. & $\begin{array}{l}\% \text { blijvend grasland van de totale } \\
\text { bedrijfsoppervlakte }\end{array}$ & $\begin{array}{l}\text { Belangrijke indicator voor de hoeveelheid } \\
\text { organische stof rust in de bodem: hoger onder } \\
\text { blijvend dan onder tijdelijk grasland. }\end{array}$ \\
\hline d. & Grondbewerking bouwland/voedergewassen & $\begin{array}{l}\text { Grondbewerkingen leiden tot een afbraak van } \\
\text { organische stof en verstoring van } \\
\text { bodembiodiversiteit. }\end{array}$ \\
\hline e. & $\begin{array}{l}\text { Organische stofbalans bouwland/ } \\
\text { voedergewassen (verschil tussen aan- en } \\
\text { afvoer van organische stof) }\end{array}$ & $\begin{array}{l}\text { Geeft inzicht in de verandering van de hoeveelheid } \\
\text { organische stof in de bodem; goede indicator voor } \\
\text { impact van bedrijfsvoering op hoeveelheid } \\
\text { organische stof. }\end{array}$ \\
\hline f. & $\begin{array}{l}\% \text { toepassing groenbemester na teelt } \\
\text { voedergewas }\end{array}$ & $\begin{array}{l}\text { Zorgt voor behoud van nutriënten in de bodem en } \\
\text { draagt bij aan opbouw van organische stof in } \\
\text { bodem. }\end{array}$ \\
\hline$g$ & $\mathrm{~N}$-bodemoverschot per ha & $\begin{array}{l}\text { Indicator voor emissies van stikstof naar } \\
\text { oppervlaktewater en lucht. Emissies leiden tot } \\
\text { eutrofiëring van oppervlaktewater en neerslag van } \\
\text { stikstof in natuurgebieden. }\end{array}$ \\
\hline $\mathrm{h}$ & NH3-emissie per ha & $\begin{array}{l}\text { Maatstaf voor de impact van landbouw op de } \\
\text { verzuring van bodems in natuurgebieden. }\end{array}$ \\
\hline i. & $\begin{array}{l}\text { Milieubelastingspunten }{ }^{2} \text { per ha } \\
\text { (gewasbescherming) }\end{array}$ & $\begin{array}{l}\text { Maatstaf voor de negatieve impact van } \\
\text { gewasbeschermingsmiddelen op water, bodem en } \\
\text { lucht. }\end{array}$ \\
\hline & $\begin{array}{l}\text { Gebruik van ontwormings- en } \\
\text { vliegenbestrijdingsmiddelen }\end{array}$ & $\begin{array}{l}\text { Hebben een negatieve impact op } \\
\text { bodemorganismen en vliegen en daarmee op } \\
\text { biodiversiteit. }\end{array}$ \\
\hline & $\%$ voereiwit van eigen bedrijf & $\begin{array}{l}\text { Bedoeld als overall-indicator voor de impact van } \\
\text { een bedrijf op biodiversiteit; is indirect is } \\
\text { opgebouwd uit vele van de andere indicatoren uit } \\
\text { deze lijst. }\end{array}$ \\
\hline
\end{tabular}

In de rest van deze paragraaf 3.3 worden de afwegingen die gemaakt zijn bij het selecteren van de 11 indicatoren in tabel 3.2. nader toegelicht. Naast de toelichting in deze paragraaf wordt is in bijlage 2 beschreven waarom de andere $87(=98-11)$ indicatoren die in stap 1 zijn geselecteerd niet zijn opgenomen in tabel 3.2.

\footnotetext{
2 Milieubelastingspunten zijn gebaseerd op een systematiek voor het meten van de milieubelasting bij het gebruik van gewasbeschermingsmiddelen. Deze methodiek is ontwikkeld door het Centrum voor Landbouw en Milieu (CLM) in het kader van het opstellen van een Milieumeetlat (http://www.milieumeetlat.nl/).
} 


\subsubsection{Hoofdstructuur en hiërarchie tussen indicatoren}

De twee centrale factoren achter de indicatoren in tabel 3.2 zijn het organische stofgehalte (a in tabel 3.2) en het bodemleven. Er is geen indicator voor bodemleven toegevoegd omdat deze niet breed beschikbaar is in de praktijk. Het streven naar functionele agrobiodiversiteit in de bodem loopt via de bevordering van zowel het organische stofgehalte van de bodem als het terugdringen van de verstoring van het bodemleven. Grasland, en met name blijvend grasland, minimale grondbewerkingen en groenbemesters zorgen er voor dat bestaande bodemprocessen ongestoord kunnen verlopen en dus maximaal kunnen bijdragen aan de opbouw van bodemleven dat nodig is voor het bevorderen van gewasopbrengst. De genoemde maatregelen dragen o.a. ok bij aan het vorkomen van bodemverdichting.

$\mathrm{Er}$ is bewust voor gekozen om naast het organische stofgehalte van de bodem ook de indicatoren $\mathrm{b}$ tot en met $\mathrm{f}$ ( $\%$ grasland, \% blijvend grasland, grondbewerking bouwland/voedergewassen, organische stofbalans en groenbemester) op te nemen omdat veranderingen in het organische stofgehalte op korte en middellange termijn moeilijk betrouwbaar zijn te meten (zie ook 3.4 voor toetsing van indicatoren aan criteria voor gebruik in de praktijk). Deze indicatoren zijn eenvoudiger meetbaar en kunnen door middel van maatregelen bijgestuurd worden.

De centrale factoren achter de indicatoren $\mathrm{g}$ tot en met j ( $\mathrm{N}$-bodemoverschot, NH3-emissie, milieubelastingpunten en ontwormings- en vliegenbestrijdingsmiddelen) zijn het beperken van emissies en opnieuw het voorkomen van de verstoring van bodemprocessen. De totale $\mathrm{N}$-emissies zijn gesplitst in $\mathrm{g}$ en $\mathrm{h}$ ( $\mathrm{N}$-bodemoverschot en $\mathrm{NH3}$-emissie) om zowel de impact op oppervlaktewater als die op natuurgebieden weer te geven.

De indicator k (\% voereiwit van eigen bedrijf) is bedoeld als overall indicator voor de impact op biodiversiteit.

\subsubsection{Onderlinge relaties tussen de geselecteerde indicatoren}

Het aantal geselecteerde indicatoren kon in stap 3 beperkt worden tot 11 door gebruik te maken van de verbanden tussen diverse indicatoren. In bijlage 3 zijn voor de grondsoorten zand, klei en veen de correlaties weergegeven tussen de indicatoren uit tabel 3.2 en nog enkele aanvullende indicatoren die tijdens het selectieproces ook naar voren kwamen als mogelijk relevant omdat ze een indruk geven van het niveau van één of meer drukfactoren of van functionele agrobiodiversiteit. In tabel 3.3 staan - als onderbouwing van de selectie uit tabel 3.2 - de combinaties met de sterkste correlaties. Een deel van de mogelijk relevante indicatoren uit de rechterkolom is afgevallen vanwege de sterke overlap met één of meer indicatoren uit de linkerkolom. Dit geldt voor de indicatoren $\mathrm{kg}$ meetmelk per ha, Pbodemoverschot per ha, N2O per ha, CO2-equivalenten per ha (= broeikasgassen totaal) en $\mathrm{CO} 2$ en methaanemissie. Voor de indicatoren grondbewerking bouwland/voedergewassen en gebruik van ontwormings- en vliegenbestrijdingsmiddelen konden geen correlaties worden berekend omdat er voor deze indicatoren geen kwantitatieve informatie beschikbaar was binnen BIN. Deze beide indicatoren komen om die reden ook niet voor in bijlage 2.

Een aantal indicatoren blijkt sterk beïnvloed te worden door de intensiteit van het bedrijf en is daardoor onderling vrij sterk verbonden. Dit geldt voor de $\mathrm{N}$ - en P-bodemoverschotten en alle gasvormige emissies ( $\mathrm{CO} 2, \mathrm{NH} 3$ en $\mathrm{N2O}$ ). Bij $\mathrm{CO} 2$ geldt het zowel voor de zuivere $\mathrm{CO} 2$-emissie als voor de emissie van de broeikasgassen $\mathrm{CO} 2, \mathrm{CH} 4$ en $\mathrm{N} 2 \mathrm{O}$, zoals die wordt uitgedrukt in $\mathrm{CO} 2-$ equivalenten. Vanwege de sterke onderlinge correlaties is besloten om de indicatoren CO2-emissie, N2O-emissie en P-bodemoverschot niet op te nemen in de geselecteerde groep in tabel 3.2. De invloed die deze indicatoren hebben op functionele agrobiodiversiteit, wordt reeds voldoende getoond door de indicatoren $\mathrm{N}$-bodemoverschot per ha, $\mathrm{NH3}$-emissie per ha en \% voereiwit van eigen bedrijf (zie verbanden in tabel 3.3 en in bijlage 3 ). 
Tabel 3.3. Relaties tussen geselecteerde en niet-geselecteerde indicatoren uit de databases

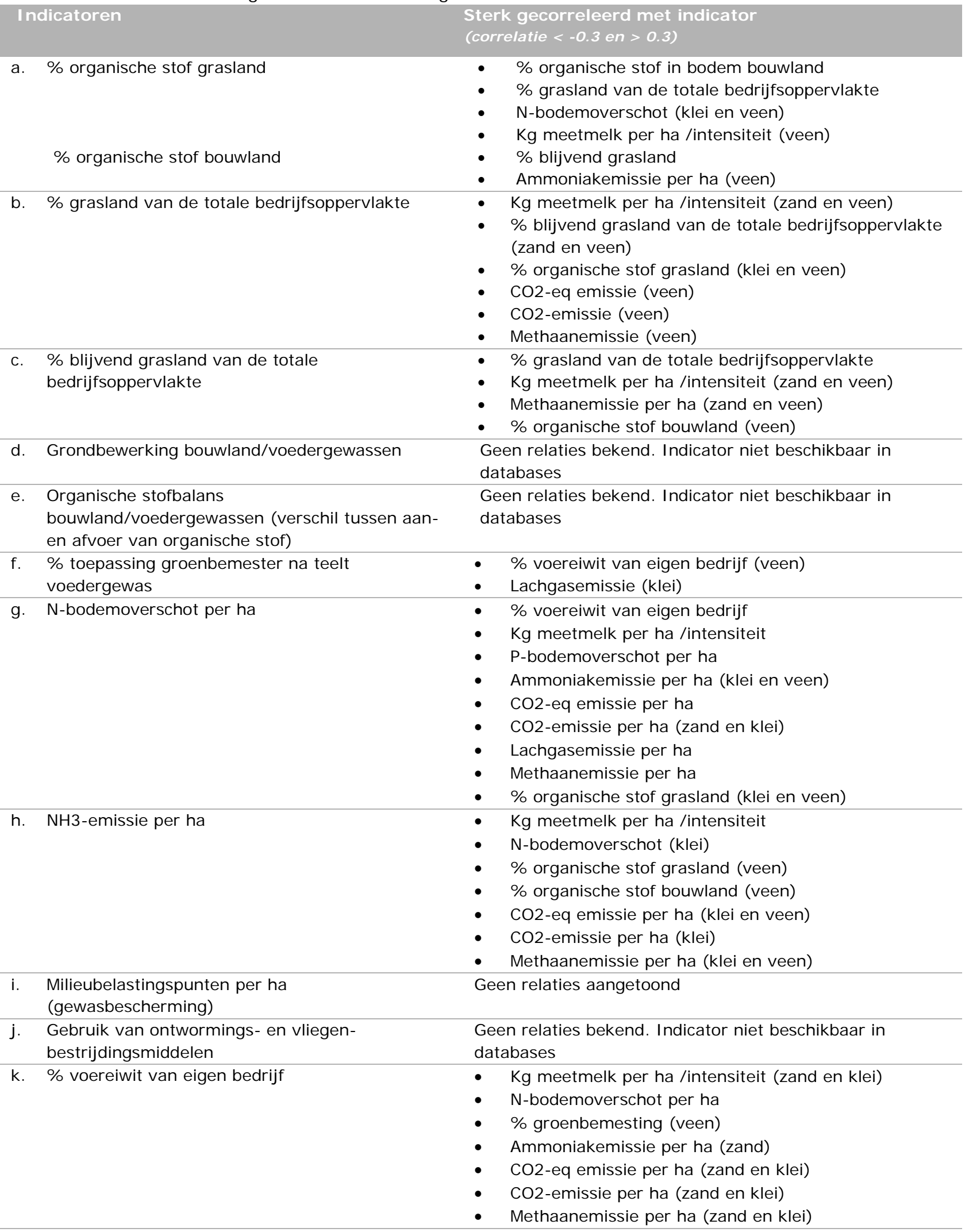

De emissies naar water, bodem en lucht zijn in tabel 3.3 uitgedrukt per ha. Dit omdat het begrip functionele agrobiodiversiteit gebonden is aan grond: hoe hoger de milieudruk per ha, des te nadeliger is dat voor de ontwikkeling van een biodivers ecosysteem op die grond (zie o.a. Erisman, 2014).

Bij het streven naar een efficiënte melkproductie is het gebruikelijk om emissies uit te drukken per kg melk. Sturen op die indicatoren leidt meestal tot intensivering van de productie per ha en als gevolg daarvan neemt de druk op biodiversiteit over het algemeen toe. 


\subsubsection{Relatie van de geselecteerde indicatoren met drukfactoren}

De opgenomen indicatoren hebben een directe of indirecte relatie (via sterk gecorreleerde effecten) met acht van de negen drukfactoren die zijn genoemd door De Bie (2013). In tabel 3.4 is met kruisjes aangegeven wanneer een indicator verbonden is met een drukfactor. Alleen voor de drukfactoren watergebruik en licht \& geluid zijn er geen relaties met de geselecteerde indicatoren.

Tabel 3.4. Relaties tussen geselecteerde indicatoren en drukfactoren

\begin{tabular}{|c|c|c|c|c|c|c|c|c|c|}
\hline Indicator & $\frac{\text { c) }}{\frac{1}{2}}$ & $\frac{y}{\frac{2}{2}}$ & 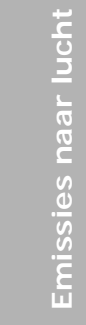 & 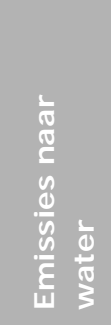 & $\begin{array}{l}\frac{5}{10} \\
\frac{0}{10} \\
\frac{2}{8} \\
\frac{1}{8}\end{array}$ & $\frac{y}{\frac{2}{2}}$ & $\begin{array}{l}\frac{y}{3} \\
\frac{3}{2} \\
\frac{0}{0} \\
\frac{0}{2} \\
\frac{1}{3} \\
\frac{10}{3}\end{array}$ & $\frac{}{\frac{2}{3}}$ & $\begin{array}{l}\text { 을 } \\
\frac{3}{0} \\
\text { 이 } \\
\text { ㅎ } \\
\text { 릅 }\end{array}$ \\
\hline $\begin{array}{l}\text { a. } \% \text { organische stof grasland } \\
\% \text { organische stof bouwland }\end{array}$ & & & & & & $X$ & & & \\
\hline $\begin{array}{l}\text { b. } \% \text { grasland van de totale } \\
\text { bedrijfsoppervlakte }\end{array}$ & & $X$ & & $X$ & & $X$ & & $X$ & \\
\hline $\begin{array}{l}\text { c. } \% \text { blijvend grasland van de totale } \\
\text { bedrijfsoppervlakte }\end{array}$ & & $X$ & & $X$ & $X$ & $X$ & & $X$ & \\
\hline $\begin{array}{l}\text { d. Grondbewerking } \\
\text { bouwland/voedergewassen }\end{array}$ & & & & & & $X$ & & & \\
\hline $\begin{array}{l}\text { e. Organische stofbalans } \\
\text { bouwland/voedergewassen (verschil } \\
\text { tussen aan- en afvoer van } \\
\text { organische stof) }\end{array}$ & & & & & & $X$ & & & \\
\hline $\begin{array}{l}\text { f. } \% \text { toepassing groenbemester na } \\
\text { teelt voedergewas }\end{array}$ & & $X$ & $X$ & $X$ & & $X$ & & & \\
\hline g. $\quad \mathrm{N}$-bodemoverschot per ha & & & $X$ & $X$ & $X$ & & & & \\
\hline h. NH3-emissie per ha & & & $X$ & & $X$ & & & & \\
\hline $\begin{array}{l}\text { i. Milieubelastingspunten per ha } \\
\text { (gewasbescherming) }\end{array}$ & & & & $X$ & & & & $X$ & \\
\hline $\begin{array}{l}\text { j. Gebruik van ontwormings- en } \\
\text { vliegenbestrijdingsmiddelen }\end{array}$ & & & & $X$ & & & & $X$ & \\
\hline k. $\%$ voereiwit van eigen bedrijf & $x$ & $x$ & $x$ & $x$ & $x$ & $x$ & & & \\
\hline
\end{tabular}

\subsubsection{Systeemanalyse: relaties tussen de geselecteerde indicatoren en} functionele agrobiodiversiteit binnen de context van een melkveebedrijf

Onderstaande beschrijvingen voor de 11 geselecteerde indicatoren zijn - met uitzondering van organische stof in de bodem en NH3-emissie per hectare - overgenomen uit Van Eekeren et al. (2015).

a. \% organische stof in bodem

Het organische stofgehalte in de bodem heeft effect op de bodemkwaliteit; onder meer op de aspecten nutriëntenlevering en -binding, maar ook op bodembiodiversiteit en functionele agrobiodiversiteit (Faber et al., 2009). Het wordt vaak bepaald via het gloeiverlies en is een resultante van het management waaronder het grondgebruik (grasland/bouwland, leeftijd grasland), grondbewerking en bemesting. In die zin zou het een hele interessante indicator zijn, omdat het aangeeft hoe het met organische stofgehalte in de bodem gesteld is. Doordat een meetbare verandering van het organische stofgehalte vaak tijd nodig heeft en de variatie binnen een zelfde perceel hoog is, is het moeilijk om op korte en middellange termijn een verandering in het organische stofgehalte betrouwbaar te meten. Daardoor is het \% organische stof op korte termijn een minder goede indicator. Het \% organische stof is een indirecte indicator voor functionele agrobiodiversiteit op een bedrijf. 
b. \% grasland van de totale bedrijfsoppervlakte

Veel melkveebedrijven hebben grasland en bouwland (vaak snijmaïs). Bedrijven die aan de derogatie voldoen, hebben minimaal $80 \%$ grasland en maximaal $20 \%$ bouwland. Grasland scoort beter voor biodiversiteit en haar functies dan bouwland. Volgens Reidsma et al. (2006) ligt de ecosysteemkwaliteit van extensief beheerd grasland op $40 \%$ en van intensief beheerd grasland nog altijd op $20 \%$, tussen die van extensief (25\%) en intensief beheerd bouwland ( $10 \%$ ) in. De genoemde percentages zijn ten opzichte van ongestoord land, waarvoor een percentage van 100 geldt. Intensiever landgebruik zoals bouwland leidt tot bodemvoedselwebsystemen die minder sterk zijn voor wat betreft het aantal taxonomische groepen, maar ook tot een kleinere diversiteit in functionele groepen (Tsiafouli et al., 2015) en tot minder verbindingen tussen organismen (Creamer et al., 2015) en een lagere abundantie (De Vries et al., 2013). Hoe meer grasland in het bedrijfssysteem, des te beter voor het organische stofgehalte van de bodem en de bodembiodiversiteit, en uiteindelijk ook voor functies als grasproductie (o.a. N-leverend vermogen), milieufuncties (o.a. waterregulatie) en biodiversiteit (o.a. weidevogels) (Van Eekeren et al., 2008 en Van Eekeren et al., 2010). Het aandeel grasland is een indirecte indicator en een maatregelenindicator voor meer functionele agrobiodiversiteit op het bedrijf. Het heeft effect op de drukfactoren landgebruik, emissies naar water, bodemgebruik en middelengebruik (het gebruik van herbiciden is over het algemeen lager op grasland dan bouwland).

c. \% blijvend grasland van de totale bedrijfsoppervlakte

Naast het aandeel grasland, speelt ook de leeftijd van het grasland een belangrijke rol. Hoe ouder het grasland, hoe minder bodembewerking is toegepast, hoe meer het ecosysteem intact blijft en hoe meer kans voor diversiteit boven en onder de grond. Doordat er geen grondbewerking wordt uitgevoerd, ontstaat er ondergronds een stabiel milieu met voldoende voeding en neemt de bodembiodiversiteit toe. Onderzoek door Van Eekeren et al. (2008) laat zien dat de bodemdiversiteit van regenwormen (aantal soorten regenwormen) nematoden (Maturity Index) en microbiologie (helling van CLPP) hoger is onder oud grasland (36 jaar) dan onder tijdelijk grasland ( 3 jaar). In ouder grasland loopt het organische stofgehalte op (figuur 3.1) en dit is gekoppeld aan de stijging van bodembiodiversiteit en functionele agrobiodiversiteit (Faber et al., 2009). Leeftijd van grasland heeft met name een positief effect op de bodembiodiversiteit. De bovengrondse botanische samenstelling hangt weliswaar gedeeltelijk met de leeftijd van het grasland samen, maar wordt daarnaast ook in belangrijke mate bepaald door het graslandmanagement (o.a. gebruikte grassoorten bij inzaai, gebruik herbiciden en bemesting) en de grondsoort. De leeftijd van grasland is daarom een indirecte indicator en een maatregelindicator voor meer functionele agrobiodiversiteit op het bedrijf. Het heeft effect op de drukfactoren landgebruik, emissies naar water, bodemgebruik en middelengebruik. Omdat leeftijd van grasland niet wordt geregistreerd, hebben we gekozen voor de indirecte indicator \% blijvend grasland.

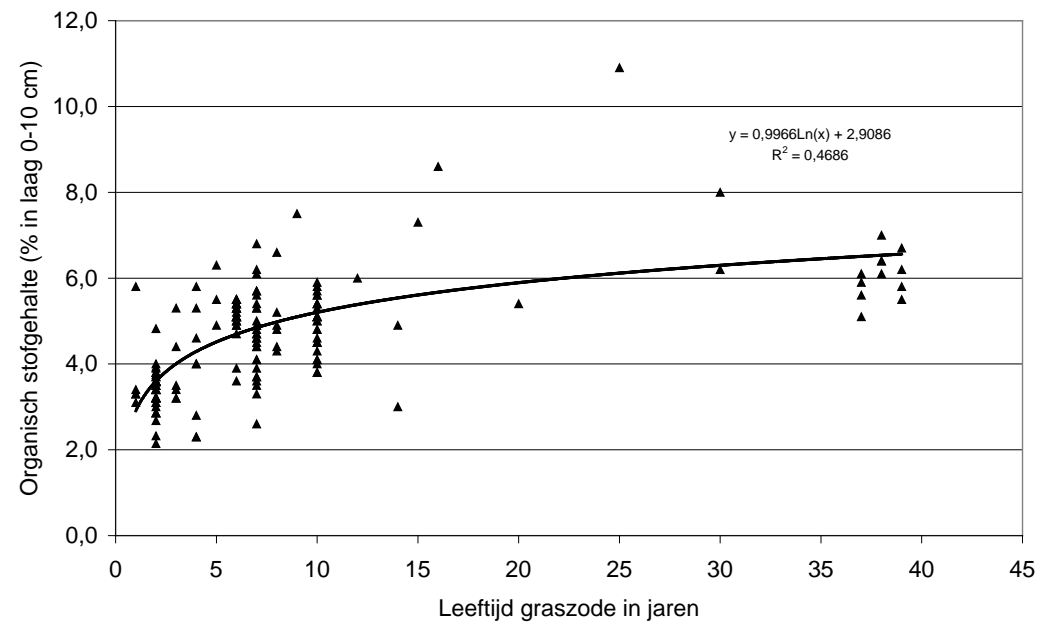

Figuur 3.1. Relatie leeftijd grasland en organisch stofgehalte (van Eekeren en Bokhorst, 2009) 
Normaliter wordt bouwland geploegd, een zogenaamde kerende grondbewerking. Een dergelijke intensieve grondbewerking op bouwland stimuleert de afbraak van organische stof. Met een nietkerende grondbewerking of minimale grondbewerking wordt organische stof behouden en blijven gewasresten in de bovengrond (Holland, 2004). De effecten van grondbewerking op biodiversiteit zijn echter niet eenduidig, en hangen af van organismen en van bodemtypes. Een recente review van Duits onderzoek naar het effect van grondbewerkingsintensiteit, laat zien dat de abundantie en diversiteit van regenwormen toeneemt bij afnemende grondbewerking (Van Capelle et al., 2012). Met name regenwormen zijn 'ecosystem engineers'. Zij dragen bij aan het vergroten van het poriënvolume in de grond, het verstevigen van de draagkracht door de vorming van aggregaten en aan de vergroting van de waterinfiltratie en het waterbergend vermogen. Hiermee vervullen ze een aantal belangrijke functies voor het landbouwsysteem. De conclusie van de Duitse review is echter dat de beslissing om een bepaald grondbewerkingssysteem te kiezen, individueel per bedrijf en per grondsoort genomen moet worden. Op melkveebedrijven hebben grondbewerkingen rond de omzetting van grasland naar bouwland veel invloed op het verlies aan bodembiodiversiteit. Met name in het jaar na deze omzetting kan een minimale grondbewerking het verlies aan bodembiodiversiteit reduceren (Deru et al., ongepubliceerde gegevens). Aangezien grasland voor biodiversiteit op een melkveebedrijf de voorkeur heeft boven bouwland (Reidsma et al., 2006), valt deze indicator wat betreft rangorde onder het aandeel grasland van het totale areaal. Grondbewerking bouwland is een maatregelenindicator die door een lagere afbraak van organische stof ook bijdraagt aan de indicator organische stofbalans bouwland/voedergewassen. Deze indicator heeft betrekking op de drukfactor bodemgebruik.

e. Organische stofbalans bouwland/voedergewassen (verschil tussen aan- en afvoer van organische stof)

De organische stofbalans van een perceel is de balans tussen de aanvoer van effectieve organische stof (organische stof die binnen één jaar nog niet is afgebroken) en de afbraak van bodemorganische stof. Wat betreft functionele agrobiodiversiteit op een melkveebedrijf heeft grasland in principe de voorkeur boven bouwland (Reidsma et al., 2006). Grasland bouwt onder andere organische stof op. Bouwland heeft over het algemeen een dalend of licht stabiliserend effect op het organische stofgehalte. De organische stofbalans op bouwland zou daarmee een indicator zijn die die pas relevant is na de indicator aandeel grasland van het totale areaal of te wel met een hoog aandeel grasland is de indicator organische stofbalans minder relevant. Het organische stofgehalte in de bodem van bouwland heeft effect op de bodembiodiversiteit en functionele agrobiodiversiteit (Faber et al., 2009). Indicatoren als de grondbewerking op bouwland en het aandeel bouwland dat in de winter begroeid is, hebben onder andere effect op deze indicator. De organische stofbalans heeft effect op de drukfactor bodemgebruik.

f. \% toepassing groenbemester na teelt voedergewas

Na de oogst van snijmaïs is het belangrijk voor de vastlegging van residuele stikstof, de organische stofvoorziening, bodemstructuurverbetering en de voeding en bescherming van het bodemleven, dat bouwland begroeid de winter in gaat. Dit kan via een vanggewas/groenbemester of via het bouwplan (bijvoorbeeld inzaai van wintergraan of herinzaai van grasland). Voor specifieke faunasoorten die zaad eten is juist een onbewerkte stoppel interessant. Geploegd en onbegroeid bouwland biedt echter weinig voedselbronnen voor fauna, omdat de gewasresten ondergewerkt zijn en er geen gewas groeit (Holland, 2004). Let wel: grasland heeft de voorkeur boven bouwland voor functionele agrobiodiversiteit op een melkveebedrijf (Reidsma et al., 2006), dus deze indicator valt in rangorde onder de indicator aandeel grasland van het totale areaal. In beperkte mate draagt een vanggewas of groenbemester ook bij aan de organische stofaanvoer (Van Schooten et al., 2006) en daarmee aan de indicator voor de organische stofbalans op bouwland/voedergewassen. Het \% toepassing groenbemester na teelt voedergewas is een maatregelenindicator voor functionele agrobiodiversiteit op een bedrijf, die betrekking heeft op de drukfactoren bodemgebruik en emissies naar water. 
Het totale stikstofbedrijfsoverschot is de som van alle aangevoerde stikstof op het bedrijf minus alle afgevoerde stikstof. Het stikstofbodemoverschot wordt in de Kringloopwijzer bepaald door de verliezen naar de lucht $\left(\mathrm{NH}_{3}\right.$ en $\mathrm{N}_{2} \mathrm{O}$ ) van het $\mathrm{N}$-bedrijfsoverschot af te trekken. Hoe lager de stikstofverliezen naar de bodem, hoe minder risico op uit- en afspoeling naar de bodem en het grond- en oppervlaktewater. Het stikstofbodemoverschot is daarmee een indicator voor de belasting van het bodem- en watersysteem. Deze indicator heeft veel directe en indirecte relaties met biodiversiteit (de Bie, 2013; Erisman et al., 2014; Erisman et al., 2015). Het N-

bodemoverschot per ha en is daarmee een indirecte indicator voor functionele agrobiodiversiteit op een melkveebedrijf. Het stikstof bodemoverschot heeft effect op de drukfactor emissies naar water.

h. NH3-emissie per ha

NH3-emissie heeft veel directe relaties met biodiversiteit (de Bie, 2013; Erisman et al., 2014; Erisman et al., 2015) en is daarmee een indirecte indicator voor functionele agrobiodiversiteit op een bedrijf. NH3-emissie per ha heeft effect op de drukfactor emissies naar lucht.

i. Milieubelastingspunten per ha (gewasbescherming)

In de veehouderij beperkt het gebruik van gewasbeschermingsmiddelen zich vaak tot herbiciden. Het gebruik van herbiciden op grasland ter beheersing van (on)kruiden leidt tot een verarming van de botanische samenstelling van grasland, wat resulteert in een lagere ondergrondse en bovengrondse biodiversiteit. De drift van herbiciden naar aangrenzende habitats zorgt daar ook voor veranderingen in biodiversiteit (Pellissier et al., 2014). Als herbiciden echter gebruikt worden als onderhoudsmaatregel om graslandvernieuwing door middel van herinzaai te voorkomen, dan zijn ze te prefereren boven het scheuren van grasland. In de maïsteelt concentreert zich het herbicidegebruik op het eventuele doodspuiten van de groenbemester met glyfosaat en één of twee onkruidbespuitingen (als maatregel om minder werkzame stof te gebruiken). Vanuit het effect op waterkwaliteit en mogelijk ook diergezondheid is het aan te bevelen het middelengebruik zoveel mogelijk te reduceren. Onderzoek in Denemarken heeft aangetoond dat mensen en dieren glyfosaat en afbraakproducten binnen krijgen via de consumptie van producten waarop glyfosaat is gebruikt (Krüger et al., 2014). Daarnaast heeft glyfosaat een effect op de diversiteit van de microbiologie in het maagdarmkanaal van de koe (Ackermann et al., 2015) en zijn er aanwijzingen dat dit uiteindelijk het immuunstelsel aantast (Schrödl et al., 2014). Het aantal milieubelastingspunten is een maatregelenindicator en heeft effect op de drukfactor middelengebruik.

\section{j. Gebruik van ontwormings- en vliegen-bestrijdingsmiddelen}

Via de mest werken antibiotica, ontwormings- en pour-on-vliegenbestrijdingsmiddelen door in het milieu. Dit leidt uiteindelijk tot het doorgeven van antibioticaresistentie in het milieu, maar ook tot sterfte van insecten en andere fauna in mest en bodem (o.a. Wardhaugh et al., 1998; Lumaret \& Faiek, 2002; Vale et al., 2004 ). Dit laatste heeft uiteindelijk niet alleen effect op functionele agrobiodiversiteit (bijvoorbeeld mestafbraak) maar ook op de fauna hoger in de voedselketen (o.a. minder voedsel voor vogels). Reductie van antibiotica, ontwormingsmiddelen en vliegenbestrijdingsmiddelen is enerzijds een maatregelenindicator, maar reductie van antibiotica zou ook een effectindicator kunnen zijn van weerbaarder vee. De reductie van vliegenbestrijdingsmiddelen zou ook een effectindicator kunnen zijn van meer functionele agrobiodiversiteit op het erf, bijvoorbeeld meer zwaluwen die de vliegen beheersen. Deze indicator heeft effect op de drukfactor middelengebruik.

k. \% voereiwit van eigen bedrijf

Eiwit is belangrijk voor het rantsoen van melkkoeien. Eiwit is voor een groot deel afkomstig uit gras en krachtvoerachtige gewassen, waaronder soja. Het percentage eiwit van eigen land hangt samen met biodiversiteit op het eigen melkveebedrijf en biodiversiteit in de regio's waar krachtvoerachtige gewassen zoals soja worden geproduceerd:

o Het percentage eiwit van eigen land geeft een mate van zelfvoorziening aan in voerproductie en is negatief gecorreleerd met de intensiteit van melkveebedrijven uitgedrukt in melkproductie per ha. Allan et al. (2014) laten zien dat bij hogere bemestingsniveaus, minder weidegang en een hoger maairegime (een intensiever bedrijf) de biodiversiteit afneemt. 
o Het percentage eiwit van eigen land zegt iets over het aandeel grasland van een melkveebedrijf. Om meer eiwit van eigen land te kunnen produceren, is meer grasland nodig. Grasland scoort beter voor biodiversiteit en haar functies dan bouwland (Reidsma et al., 2006).

o Het percentage eiwit van eigen land is ook een indicator voor de voetafdruk van een bedrijf en voor de hoeveelheid aangekocht krachtvoer en hoogwaardige grondstoffen, zoals soja. Dit heeft effect op de biodiversiteit in andere regio's van de wereld.

o Het percentage eiwit van eigen land zegt verder iets over de efficiëntie waarmee melk wordt geproduceerd en heeft dus ook een relatie met emissies naar de lucht, bodem en water, o.a. van stikstof en broeikasgassen die zorgen voor aantasting van de biodiversiteit elders.

Percentage eiwit van eigen land is een indirecte indicator voor biodiversiteit en een interessante sleutel-indicator om te sturen op meer functionele agrobiodiversiteit op een bedrijf. Deze indicator heeft effect op de drukfactoren energie, landgebruik, emissies naar lucht en water, landschap en bodemgebruik.

\subsection{Stap 4: Toetsing indicatoren aan criteria voor gebruik in praktijk}

De resultaten van de toetsing van de geselecteerde indicatoren aan criteria voor gebruik in de praktijk staan in tabel 3.5. In de kolommen die te maken hebben met beschikbaarheid van data is zo mogelijk de databron vermeld waarin de betreffende indicator is opgeslagen. Onder borging is de borgingsinstantie vermeld. Wanneer er een nulmeting beschikbaar is, is aangegeven welke organisatie hierover beschikt. 
Tabel 3.5. Toetsing van indicatoren aan criteria voor bruikbaarheid voor monitoring op Nederlandse melkveebedrijven

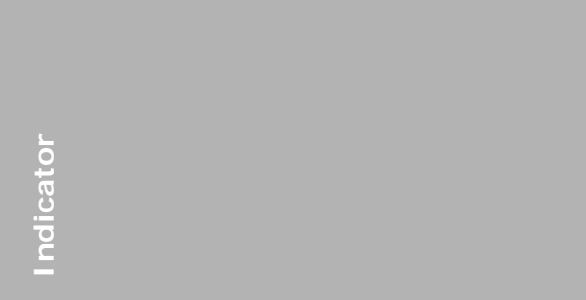

a. \% organische stof in bodem

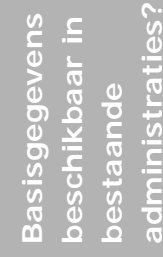

-

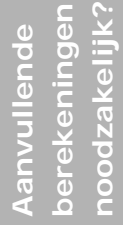

a

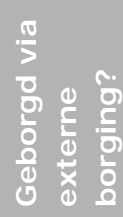

के

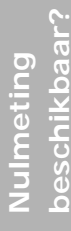

$+$

\begin{tabular}{|c|c|c|c|c|c|}
\hline b. & $\begin{array}{l}\% \text { grasland van de totale } \\
\text { bedrijfsoppervlakte }\end{array}$ & KLW & KLW & KLW & KLW \\
\hline C. & $\begin{array}{l}\% \text { blijvend grasland van de totale } \\
\text { bedrijfsoppervlakte }\end{array}$ & KLW & KLW & KLW & KLW \\
\hline d. & $\begin{array}{l}\text { Grondbewerking } \\
\text { bouwland/voedergewassen }\end{array}$ & Nee & Ja & Nee & nee \\
\hline e. & $\begin{array}{l}\text { Organische stofbalans } \\
\text { bouwland/voedergewassen }\end{array}$ & Nee & Ja & Nee & nee \\
\hline f. & $\begin{array}{l}\% \text { toepassing groenbemester na teelt } \\
\text { voedergewas }\end{array}$ & KLW & KLW & KLW & KLW \\
\hline g. & N-bodemoverschot per ha & KLW & KLW & KLW & KLW \\
\hline h. & NH3-emissie per ha & KLW & KLW & KLW & KLW \\
\hline i. & $\begin{array}{l}\text { Milieubelastingspunten per ha } \\
\text { (gewasbescherming) }\end{array}$ & Nee/GO* & CLM/BIN & nee & Nee \\
\hline j. & $\begin{array}{l}\text { Gebruik van ontwormings- en } \\
\text { vliegenbestrijdingsmiddelen }\end{array}$ & nee & nee & nee & Nee \\
\hline k. & $\%$ voereiwit van eigen bedrijf & KLW & KLW & KLW & KLW \\
\hline
\end{tabular}

CBS = Centraal Bureau voor de Statistiek, CLM = Centrum voor Landbouw en Milieu, GO = gecombineerde opgave aan RVO, GR = grondonderzoek, KLW= Kringloopwijzer, LG = laboratorium grond- en gewasonderzoek, SCAN = Uitkeringsinstantie.

Zie nadere toelichting in paragraaf 3.4 voor kanttekeningen rond externe borging en nulmeting. 
Hieronder wordt de toetsing van de indicatoren aan de criteria voor bruikbaarheid nader toegelicht en worden suggesties gedaan voor vervolgonderzoek om indicatoren te ontwikkelen of bruikbaar te maken voor monitoring.

a. \% organische stof in bodem

Deze indicator is beschikbaar via grond- en gewasonderzoek en zou geborgd kunnen zijn wanneer het monsternameprotocol geborgd is. Zoals hiervoor ook reeds twee keer benoemd, is het grote nadeel van deze indicator dat veranderingen in de tijd op korte termijn (één of enkele jaren) niet betrouwbaar te meten zijn. Om die reden is deze indicator momenteel niet geschikt voor monitoring.

b. \% grasland van de totale bedrijfsoppervlakte Deze indicator komt beschikbaar vanuit de Kringloopwijzer. Het beoordelen van de Kringloopwijzer als afrekeninstrument (o.a. door nutriëntenstromen te valideren) is een lopend onderzoek van de Commissie van Deskundigen Meststoffenwet (CDM) dat volgens plan in 2016 wordt afgesloten. Op basis van de veronderstelling dat deze indicator binnen de Kringloopwijzer als voldoende geborgd wordt beschouwd, is het een bruikbaar indirecte indicator. In 2013 is door Holster et al. (2013) reeds een verkennend onderzoek uitgevoerd naar de haalbaarheid van borging van de Kringloopwijzer als verantwoordingsinstrument voor bedrijfsspecifieke milieuprestaties. Voor een nadere borging zou de inzet van drones of satellietbeelden onderzocht kunnen worden.

c. \% blijvend grasland van de totale bedrijfsoppervlakte Ook deze indicator komt voor in de Kringloopwijzer. Hier gelden dezelfde randvoorwaarden en conclusies als onder $b$.

d. Grondbewerking bouwland/voedergewassen Momenteel worden geen gegevens over grondbewerkingen op bouwland vastgelegd. Om deze indicator te kunnen gebruiken, zal dus eerst een registratiesysteem moeten worden ontworpen. Daarmee is deze indicator op korte termijn niet bruikbaar. Op langere termijn mogelijk wel, maar pas na aanvullend onderzoek naar het omzetten van bewerkingen in een geborgde indicator.

e. Organische stofbalans bouwland/voedergewassen

Binnen de Kringloopwijzer komt de indicator 'aanvoer effectieve organische stof' voor, dat wordt berekend uit gegevens die binnen de Kringloopwijzer beschikbaar zijn, in combinatie met aanvullende uitgangspunten. Hiermee komt informatie beschikbaar over de aanvoer van organische stof. De informatie m.b.t. de afbraak van organische stof is echter nog niet beschikbaar in bestaande systemen. Mogelijk kan onderzocht worden of die binnen de Kringloopwijzer ook geschat kan worden uit beschikbare gegevens. Mogelijk zijn hiervoor extra metingen en/of extra data nodig. Daarmee is deze indicator op korte termijn niet bruikbaar. Op middellange termijn mogelijk wel, maar pas na aanvullend onderzoek naar het beter meten of schatten van de afbraak van organische stof op jaarbasis.

f. \% toepassing groenbemester na teelt voedergewas Ook deze indicator komt voor in de Kringloopwijzer. Hier gelden verder de zelfde opmerkingen als onder b. Ook hier geldt dat het nuttig is om te verkennen of satellietbeelden toegevoegde waarde hebben voor de borging. Deze beelden kunnen mogelijk ook de hoeveelheid geteelde biomassa aantonen en daarmee een aanvullende indicatie leveren voor de organische stoftoename.

g. N-bodemoverschot per ha

Ook deze indicator komt voor in de Kringloopwijzer. Hier gelden dezelfde opmerkingen als onder b.

h. NH3-emissie per ha Ook deze indicator komt voor in de Kringloopwijzer. Hier gelden dezelfde opmerkingen als onder b.

i. Milieubelastingspunten per ha (gewasbescherming)

De systematiek van milieubelastingspunten is ontwikkeld door CLM in het kader van het opstellen van een Milieumeetlat. Deze wordt ook toegepast binnen het BIN. Voor zover bekend wordt deze niet binnen andere administratieve systemen toegepast en worden er dus op praktijkschaal geen data over vastgelegd op grote aantallen bedrijven. Voor de Gecombineerde Opgave van 2016 is aan bedrijven gevraagd om het gebruik van gewasbeschermingsmiddelen op te geven. Het is nog te vroeg om de bruikbaarheid van deze gegevens te beoordelen. Daarmee is deze indicator op korte termijn niet bruikbaar. Op langere termijn mogelijk wel, maar pas na aanvullend onderzoek naar het vastleggen van het gebruik van gewasbeschermingsmiddelen op melkveebedrijven en het omrekenen van dat gebruik naar milieubelastingspunten.

j. Gebruik van ontwormings- en vliegen-bestrijdingsmiddelen Momenteel worden geen gegevens over het gebruik van deze middelen vastgelegd. Om deze indicator voor het gebruik van deze middelen te ontwikkelen, is nader onderzoek noodzakelijk. Mogelijk kan dat op langere termijn leiden tot een indicator. 
k. \% voereiwit van eigen bedrijf

Deze indicator is te berekenen vanuit de Kringloopwijzer waarin het aandeel eigen $\mathrm{N}$ in totale voeraanbod voor het vee wordt weergegeven. Eventueel kan in plaats van "\% voereiwit" ook uitgegaan worden van het direct beschikbare "\% voer- $\mathrm{N}$ van eigen bedrijf". Zie verder de opmerkingen over borging onder $b$.

Een belangrijke conclusie is dat de beoordeling van de borging van indicatoren binnen de Kringloopwijzer veel invloed heeft op de beschikbaarheid van de indicatoren \% grasland, \% blijvend grasland, \% toepassing groenbemester na teelt voedergewas, $\mathrm{N}$-bodemoverschot per ha, NH3-emissie per ha en \% voereiwit van eigen bedrijf. 


\section{Conclusies: KPI's voor monitoring}

Na bovenstaande analyse zijn er $10 \mathrm{KPI}$ 's geselecteerd. Daarnaast hebben we onderscheid gemaakt tussen de mogelijkheden voor implementatie op de korte, middellange en lange termijn. De KPI's voor middellange en lange termijn vereisen meer onderzoek om ze te ontwikkelen en te borgen. Het is mogelijk dat KPI's voor middellange en lange termijn naar voren kunnen worden gehaald door de meer prioriteit te geven aan de verdere ontwikkeling ervan. Op basis van de doorlopen stappen komen we tot de onderstaande KPI's.

Op basis van de toetsing in dit rapport zijn de volgende KPI's als integrale set bruikbaar voor de monitoring van biodiversiteit op melkveebedrijven.

\section{I mplementeerbaar op korte termijn (binnen 1 à 2 jaar)}

a. \% grasland van de totale bedrijfsoppervlakte

b. \% blijvend grasland van de totale bedrijfsoppervlakte

c. \% toepassing groenbemester na teelt voedergewas

d. N-bodemoverschot per ha

e. NH3-emissie per ha

f. \% voereiwit van eigen bedrijf

De bovenstaande indicatoren zijn beschikbaar via de Kringloopwijzer en daarmee relatief eenvoudig implementeerbaar.

\section{I mplementeerbaar op middellange termijn ( 2 à 3 jaar)}

g. Organische stofbalans bouwland/voedergewassen

Voor deze KPI moet nader onderzocht worden of via de informatiestromen van de Kringloopwijzer inschattingen gemaakt kunnen worden van de afbraak van organische stof. Binnen Kringloopwijzer is reeds informatie bekend over de aanvoer van organische stof.

\section{I mplementeerbaar op lange termijn (meer dan $\mathbf{3}$ jaar)}

h. Grondbewerking bouwland/voedergewassen

i. Milieubelastingspunten per ha (gewasbescherming)

j. Gebruik van ontwormings- en vliegenbestrijdingsmiddelen

Voor deze KPI's zullen aanvullende gegevens verzameld, vastgelegd en geborgd moeten worden. 


\subsection{Kanttekeningen en beperkingen onderzoek}

\section{Beperkingen door bestaande databases en pijler 1 als uitgangspunt te nemen}

In dit rapport waren algemeen beschikbare indicatoren het uitganspunt voor het beschreven onderzoek naar indicatoren voor het kenschetsen van de functionele agrobiodiversiteit en de impact van drukfactoren op biodiversiteit. Op dit moment zijn in Nederland geen algemeen gehanteerde indicatoren over biodiversiteit(smaatstaven) of ecologische kenmerken van bedrijven beschikbaar. Wanneer uit het lopende onderzoek dat gericht is op het monitoren van biodiversiteit voor de pijlers 2 tot en met 4 (zie paragraaf 1.2.2) aanvullende indicatoren voor biodiversiteit op en rond het melkveebedrijf komen, ligt het voor de hand opnieuw na te gaan welke combinatie van KPI's een zo goed mogelijk integraal beeld kan schetsen van de bijdrage van een melkveebedrijf aan biodiversiteit. Ook nieuwe ontwikkelingen rond graslandmanagement (bijvoorbeeld de praktijk om naast grassen ook kruiden in te zaaien in grasland) kunnen mogelijkheden bieden voor KPI's die beter aansluiten bij biodiversiteitsdoelen.

Aanbevolen wordt verder om in de toekomst nader onderzoek te doen naar meer directe indicatoren die de (functionele agro-) biodiversiteit op een bedrijf kunnen beschrijven. Dit zou kunnen door bovengrondse soorten te meten (bijv. het voorkomen van kruiden) of soorten bodemleven beter in kaart te brengen. Mogelijk kunnen beelden die gemaakt zijn met drones of satelieten hier ook een rol bij vervullen.

\section{Percentage voereiwit van eigen bedrijf als KPI}

De KPI \% voereiwit van eigen bedrijf is een indicator die vele aspecten in zich herbergt. De indicator is sterk gecorreleerd met intensiteit. Bij een laag \% voereiwit van eigen bedrijf zal veel eiwit (voer) aangekocht worden dat elders is geproduceerd. Vervolgens roept dat de vraag op hoe schadelijk die productie elders is voor de (mondiale) biodiversiteit. Elders kan zijn in de directe omgeving van het bedrijf, in Nederland of Europa, maar het kan ook eiwit betreffen dat bijvoorbeeld in Brazilië wordt geproduceerd. Deze KPI kan dus ook worden gezien als indicator voor de mondiale voetafdruk van het Nederlandse melkveebedrijf waarvoor die wordt berekend. Het is een zeer samengestelde KPI is die veel aspecten in zich herbergt. Dat maakt hem geschikt als snelle indicator, maar tegelijkertijd ook lastig om te interpreteren hoe deze bijdraagt aan het realiseren van welke doelen. De overige KPI's uit de serie aanbevolen KPI's zijn veel gerichter: ze dragen of bij aan verhoging organische stof, aan de vermindering eutrofiëring of zure neerslag, enz.

Verder roept de KPI \% voereiwit van eigen bedrijf de vraag op: is aanvoer van eiwit van buiten het bedrijf schadelijk voor biodiversiteit? Het antwoord op deze vraag hangt sterk af van de wijze waarop dat ruwvoer buiten het bedrijf wordt geproduceerd: houdt de producent ervan rekening met biodiversiteitsdoelen? Dat zou eventueel ook een eis kunnen zijn van de koper van het voereiwit. In dat kader wordt o.a. door de organisatie Round Table Responsible Soy Association ${ }^{3}$ gewerkt aan het verduurzamen van de productie van soja in gebieden waar dit gewas wordt geteeld voor o.a.

Europese melkveehouders. Het is ook mogelijk dat de producent meer kan bijdragen aan biodiversiteit (of het voorkomen van biosdiversiteitsverlies) dan de koper zou doen bij productie van extra voereiwit op het eigen bedrijf. De indicator roept ook de vraag op of intensiteit een criterium moet zijn voor de beoordeling op biodiversiteit of dat het werken aan en beoordelen van biodiversiteit centraal moet staan, los van intensiteit. Intensieve bedrijven kunnen in principe ook bijdragen aan verbetering van biodiversiteit door een scala van maatregelen.

De definitie "van eigen bedrijf" kan eventueel ook worden uitgebreid tot "uit de eigen regio" waarbij dan vervolgens een afstandscriterium nodig is om de eigen regio te begrenzen. Een afstandscriterium roept opnieuw de vraag op of deze indicator en het afstandscriterium wel daadwerkelijk een bijdrage leveren aan het verbeteren van de biodiversiteit op de grond waar het aangekochte voer wordt geproduceerd. In plaats van deze indicator zou ook te overwegen zijn om de biodiversiteit te beoordelen op bedrijven die dit ruwvoer produceren voor de melkveehouder, bijvoorbeeld op basis van dezelfde indicatoren die binnen de hier voorgestelde methodiek worden gebruikt. De focus komt dan meer te liggen op bijdrage aan biodiversiteit en minder op het wel of niet zelf telen van ruwvoer.

Uiteindelijk is besloten om deze KPI wel op te nemen, met name omdat deze wordt beschouwd als een indicator die een samenvatting is van alle overige indicatoren en daardoor een functie kan hebben

\footnotetext{
${ }^{3}$ http://www.responsiblesoy.org
} 
als snelle en eenvoudige indicator voor biodiversiteit op een melkveebedrijf. Aanbevolen wordt om in volgende fasen waarin het gebruik van de indicatoren in de praktijk nader wordt onderzocht, nogmaals na te gaan of deze indicator inderdaad deze rol heeft en dan ook nader vast te stellen wat de meerwaarde is van deze indicator ten opzichte van de overige.

\subsection{Vervolgstappen naar monitoring}

\section{Verdere reductie van het aantal KPI's}

Het was de ambitie van de opdrachtgever om met een zeer beperkt aantal indicatoren een beeld te schetsen van het onderdeel functionele agrobiodiversiteit op een melkveebedrijf. In het geval de opdrachtgever behoefte heeft aan een kortere lijst, kan de lijst op één of meer van de volgende wijzen verder ingeperkt worden:

- Op basis van de correlaties tussen indicatoren (zie tabel 3.3 en bijlage 3) kan ervoor gekozen worden om indicatoren te schrappen die relatief sterk zijn gecorreleerd met een andere indicator. Op basis hiervan zou percentage grasland of percentage blijvend grasland kunnen vervallen. Het percentage voereiwit van eigen bedrijf is relatief sterk gecorreleerd met het $\mathrm{N}$-bodemoverschot en eventueel zou één van die beide dus ook kunnen vervallen.

- $\quad$ Op basis van systeemanalyse kunnen indicatoren die grotendeels overlappen in hun functie binnen het systeem, elkaar vervangen. Dit geldt bijvoorbeeld voor de indicator voor grondbewerking bouwland/voedergewassen en organische stofbalans bouwland/voedergewassen. De eerste is sterker gericht op het middel; de tweede meer op het doel en zou om die reden voorkeur verdienen.

- Uiteraard is het ook mogelijk biodiversiteitsdoelen aan te scherpen of te prioriteren en op die manier indicatoren die verbonden zijn aan minder prioritaire biodiversiteitsdoelen, buiten de lijst te houden.

- Het meten van directe biodiversiteitsindicatoren en correlaties tussen indirecte en directe indicatoren kan in de toekomst leiden tot nieuwe inzichten en daardoor ook tot het toevoegen of weglaten van één of meer KPI's.

\section{Meer aandacht voor water}

In een tweetal interviews met representanten van het Planbureau voor de Leefomgeving (PBL) en LTO Nederland is nagegaan hoe zij aankijken tegen het werken aan functionele agrobiodiversiteit op melkveebedrijven en wat dat zou kunnen betekenen voor de keuze van KPI's. Uit deze gesprekken is waterbeheer op bedrijven als belangrijkste nog ontbrekende aandachtspunt naar voren gekomen. Binnen waterbeheer is peilbeheer als eerste sub-thema genoemd in verband met de gevolgen van de agrarische bedrijfsvoering voor het proces van veeninklinking. Het tweede sub-thema is verdroging rond natuurgebieden. De bijdrage aan beide thema's zou met aanvullende indicatoren in beeld gebracht kunnen worden. Hiervoor zouden in de toekomst extra indicatoren ontwikkelen kunnen worden.

Binnen waterbeheer verdient ook het verbruik van water op het bedrijf meer aandacht. Belangrijke onderdelen van dat waterverbruik zijn de hoeveelheden water die worden gebruikt voor drinkwater vee, reinigen van melkmachineapparatuur, gebouwen en werktuigen en water gebruikt voor de voerproductie waarbij met name de beregening van gewassen op sommige bedrijven zorgt voor het verbruik van veel water.

In paragraaf 3.2. is reeds aangegeven dat het \% van het bedrijfsoppervlak waarop snijmaïs wordt geteeld, gerelateerd is aan het waterverbruik van gewassen. Omdat het \% grasland en het \% snijmaïs complementair zijn, is de gekozen KPI \% grasland daarmee ook reeds een indicator voor waterverbruik. Het toevoegen van het werkelijke verbruik van water voor irrigatie van zowel gras als voedergewassen zoals maïs, zal wel een nauwkeuriger weergave van het waterverbruik door gewassen opleveren.

\section{Extra toetsingscriteria}

Binnen het onderzoek is nog een aantal criteria in overweging genomen die uiteindelijk niet in tabel 3.5 zijn opgenomen, bijvoorbeeld omdat het meer kwalitatieve toetsingen zijn of omdat de toetsing bij nader inzien niet relevant bleek te zijn. Het gaat om de vier onderstaande criteria:

\section{Beïnvloedbaarheid door ondernemer op korte termijn ( $<\mathbf{5 j a a r )}$}

Wanneer gerichte maatregelen worden ingezet om de score voor indicator te verbeteren en wanneer deze maatregelen (nog) niet op korte termijn leiden tot een positieve ontwikkeling van de 
indicator, is een dergelijke indicator minder geschikt. Bij de doorlichting van de indicatoren voor dit criterium bleek dat alleen de indicator "\% organische stof in bodem" ongunstig scoort op dit criterium (zie ook toelichting in 3.3.4).

\section{Bruikbaarheid voor het management van het bedrijf}

Bij de toetsing aan dit criterium gaat het er vooral om of de voorgestelde KPI ondernemers uitdaagt om te werken aan verbeteringen van zowel biodiversiteit als bijvoorbeeld ook economische of technische resultaten. Bij het beoordelen van de indicatoren op dit criterium bleek dat het lastig was om daarbij een helder afgebakend referentiekader te maken. Daarnaast speelde mee dat op het moment dat de bewuste indicator ingezet zou worden als KPI en het verbeteren van deze KPI gekoppeld zou zijn aan bijv. melkprijs of imago van bedrijf, dat het dan sowieso een Indicator is dat waardevol is voor het bedrijfsmanagement. Om deze redenen is dit criterium verder niet meegenomen in de tabel.

3. Beoordeling op basis van bijdrage aan het streven naar integrale duurzaamheid Om twee redenen is dit criterium in de tabel niet opgenomen. Allereerst is bij de selectie van indicatoren in stap 3 hier reeds rekening mee gehouden. Ten tweede bepaalt vooral ook de uiteindelijk gekozen combinatie van een aantal KPI's of met de keus van het gehele pakket KPI's voor biodiversiteit wordt voldaan aan dit criterium. Toetsing aan dit criterium kan dus het beste gebeuren aan het eind van proces om te komen tot een afgewogen set KPI's. Naar onze mening levert het gebruik van de huidige combinatie van geadviseerde KPI's een integrale beoordeling op die ook zal bijdragen aan het verbeteren van meerdere andere duurzaamheidsaspecten.

4. Administratieve lasten van verzameling en borging van de KPI's

De beoordeling hiervoor gebeurde reeds door de combinatie van de criteria 1 tot en met 4 in het overzicht met criteria in tabel 3.5. Voor een aantal KPI's zijn nog aanvullende berekeningen/acties noodzakelijk om de data te kunnen verzamelen/borgen:

- Indicator voor grondbewerking bouwland/voedergewassen

- Organische stofbalans bouwland/voedergewassen

- Milieubelastingspunten per ha (gewasbescherming)

Dit betekent dat deze KPI's pas op langere termijn beschikbaar kunnen komen voor monitoring. Bovendien moeten gevolgen voor de administratieve lasten en borging van nieuw te ontwikkelen indicatoren worden geanalyseerd wanneer er meer duidelijkheid is over het proces om te komen tot die indicatoren. 


\section{Aanbevelingen voor vervolgonderzoek}

Voor de verdere uitwerking van de systematiek voor het monitoren van biodiversiteit op melkveebedrijven doen we de volgende aanbevelingen:

1. Zorg voor de borging van de geadviseerde KPI's

In 3.4 zijn diverse aanbevelingen gegeven die er voor kunnen zorgen dat de aanbevolen KPI's geborgd beschikbaar komen via een proces dat objectieve en juiste data oplevert. Het verder borgen van Kringloopwijzer en het gebruik van beelden van drones of satellieten zijn de belangrijkste.

2. Zorg voor meer inzicht in relatie tussen KPI's en directe indicatoren voor biodiversiteit Binnen de dataset kwamen geen indicatoren voor die een directe indicator voor biodiversiteit waren. Uit de bestaande administratiesystemen waren uitsluitend indicatoren beschikbaar die indirect iets zeggen over biodiversiteit. Een belangrijke vervolgstap is om deze indicatoren te valideren met directe indicatoren voor functionele agrobiodiversiteit en andere vormen van biodiversiteit op melkveebedrijven.

3. Toets de gevolgde werkwijze aan andere methoden voor monitoring van biodiversiteit In internationaal verband wordt door vele organisaties gewerkt aan richtlijnen voor het monitoren van biodiversiteit. Het is van belang deze ontwikkelingen te volgen en nieuwe benaderingen ook te screenen op meerwaarde voor toepassing in Nederland.

4. Voeg indicatoren op het gebied van waterbeheer en watergebruik toe Om meer inzicht te krijgen in de impact van melkveebedrijven op de bodemdaling op veengrond en op het verminderen van de verdrogingsproblematiek rond natuurgebieden is het nuttig om indicatoren op te nemen die hierin inzicht geven. Dit is mogelijk ook te combineren met het formuleren van één of meer KPI's voor pijler 4. Verder is het nuttig om te onderzoeken welke mogelijkheden er zijn om indicatoren voor het waterverbruik toe te voegen aan de monitoring van biodiversiteit. 


\section{Literatuur}

Ackermann, W., M. Coenen, W. Schrödl, A.A. Shehata, M. Krüger, 2015. The influence of glyphosate on the microbiota and production of botulinum neurotoxin during ruminal fermentation. Curr Microbiol. 70(3):374-82

Allan, E., O. Bossdorf, C.F. Dormann, D. Pratia, M.M. Gossner, T. Tscharntke, N. Blüthgen, M. Bellach, K. Birkhofer, S. Boch, S. Böhm, C. Börschig, A. Chatzinotas, S. Christ, R. Daniel, T. Diekötter, C. Fischer, T. Friedl, K. Glaser, C. Hallmann, L. Hodac, N. Hölzel, K. Jung, A.M. Klein, V.H. Klaus, T. Kleinebecker, J. Krauss, M. Lange, E.K. Morris, J. Müller, H. Nacke, E. Pašalić, M.C. Rillig, C. Rothenwöhrer, P. Schall, C. Scherber, W. Schulze, S.A. Socher, J. Steckel, I. Steffan-Dewenter, M. Türke, C.N. Weiner, M. Werner, C. Westphal, V. Wolters, T. Wubet, S. Gockel, M. Gorke, A. Hemp, S.C. Renner, I. Schöning, S. Pfeiffer, B. König-Ries, F. Buscot, K.E. Linsenmair, E.D. Schulze, W.W. Weisser, M. Fischer (2014). Interannual variation in land-use intensity enhances grassland multidiversity. PNAS 111(1), p.308-313

Bie, S. de, 2013. Getting to No net Loss - Exploring options for No Net Loss of biodiversity in Royal Friesland Campina, Klarenbeek, Conservation Consultancy Steven de Bie.

Van Capelle, C. S. Schrader, J. Brunotte. (2012) Tillage-induced changes in the functional diversity of soil biota - A review with a focus on German data. European Journal of Soil Biology 50: 165181.

Creamer, R.E., S.E. Hannula, J.P. van Leeuwen, D. Stone, M. Rutgers, R.M. Schmelz, P.C. de Ruiter, N. Bohse Hendriksen, T. Bolger, M.L. Bouffaud, M. Buee, F. Carvalho, D. Costa, T. Dirilgen, R. Francisco, B.S. Griffiths, R. Griffiths, F. Martin, P. Martins da Silva, S. Mendes, P.V. Morais, C. Pereira, L. Philippot, P. Plassart, D. Redecker, J. Römbke, J.P. Sousa, M. Wouterse, P. Lemanceau (2015) Ecological network analysis reveals the inter-connection between soil biodiversity and ecosystem function as affected by land use across Europe. Applied Soil Ecology (article in press).

De Vries, F.T., E. Thébault, M. Liiri, 2013. Soil food web properties explain ecosystem services across European land use systems. Proceedings of the National Academy of Sciences of the United States of America, 110, p.14296-14301

DZK, 2016. Zie: http://www.duurzamezuivelketen.nl/files/gedetailleerde-doelen-duurzamezuivelketen.pdf, voor beschrijving doelen biodiversiteit

Eekeren, N.J.M. van en J.G. Bokhorst, 2010. Bodemkwaliteit en klimaatadaptatie onder grasland op het Utrechtse zand. Rapport 2010-031LbD. Driebergen, Louis Bolk Instituut

Eekeren, N. van, L. Bommelé, J. Bloem, M. Rutgers, R.G.M. de Goede, D. Reheul, L. Brussaard (2008) Soil biological quality after 36 years of ley-arable cropping, permanent grassland and permanent arable cropping. Applied Soil Ecology. 40: 432-446.

Eekeren, N. van, H. de Boer, M.C. Hanegraaf, J.G. Bokhorst, D. Nierop, J. Bloem, T. Schouten, R.G.M. de Goede, L. Brussaard (2010) Ecosystem services in grassland associated with biotic and abiotic soil parameters. Soil Biology \& Biochemistry. 42(9): 1491-1504

Eekeren, N. van, F. Verhoeven en J.W. Erisman, 2015. Verkenning Kritische Prestatie Indicatoren voor stimulering van een biodiverse melkveehouderij. Driebergen, Louis Bolk Instituut

Erisman, J.W., J.N. Galloway, N.B. Dise, M.A. Sutton, A. Bleeker, B. Grizzetti, A.M. Leach, W. de Vries, 2015. Nitrogen: Too much of a vital resource. WWF Netherlands, Zeist, the Netherlands. 27 p.

Erisman, J.W., N. van Eekeren, W. Cuijpers en J. de Wit, 2014. Biodiversiteit in de melkveehouderij - Investeren in veerkracht en reduceren van risico's. Driebergen, Louis Bolk Instituut

Faber, J.H., Jagers op Akkerhuis, G.A.J.M., Bloem, J., Lahr, J., Diemont, W.H., Braat, L.C., 2009, Ecosysteemdiensten en bodembeheer: maatregelen ter verbetering van biologische bodemkwaliteit. Wageningen, Alterra-rapport 1813. 150 p.

Grinsven, H. van, M. van Eerdt en H. Westhoek, 2014. Landbouw en Voedsel - Balans van de leefomgeving 2014 - Deel 4. Den Haag, Planbureau voor de Leefomgeving

Holland, J.M., 2004. The environmental consequences of adopting conservation tillage in Europe: reviewing the evidence. Agriculture, Ecosystems and Environment 103, p.1-25 
Holster, H., M. de Haan, M. Plomp, M. Timmerman en M. Vrolijk, 2013. KringloopWijzer, goed geborgd!? Rapport 676 Wageningen Livestock Research, Lelystad

Jongeneel, R.A., N.B.P. Polman en L.H.G. Slangen, 2008. Why are Dutch farmers going multifunctional? Land Use Policy 25: 81-94.

Krüger, M., P. Schledorn, W. Schrödl, H.W. Hoppe, W. Lutz, A. A. Shehata, 2014. Detection of Glyphosate Residues in Animals and Humans. J Environ Anal Toxicol 2014, 4:210.

Lumaret, J.P., E. Faiek, 2002. Use of anthelmintics in herbivores and evaluation of risks for the nontarget fauna of pastures. Veterinary Research 33.5: 547-562.

Pellissier, L., M.S. Wisz, B. Strandberg, C. Damgaard, 2014. Herbicide and fertilizers promote analogous phylogenetic responses but opposite functional responses in plant communities. Environmental Research Letters, 9, p.1-9

Polman, N., M. Dijkshoorn, B. Doorneweert, P. Rijk, T. Vogelzang en S. Reinhardt, 2015. Verdienmodellen natuurinclusieve landbouw. Den Haag, LEI Wageningen UR

Reidsma, P., T. Tekelenburg, M. van den Berg, R. Alkemade, 2006. I mpacts of land-use change on biodiversity: an assessment of agricultural biodiversity in the European union. Agriculture, Ecosystems and Environment 114, p. 86-102

Reijs, J.W., G.J. Doornewaard, J.H. Jager, M.W. Hoogeveen en A.C.G. Beldman, 2016. Sectorrapportage Duurzame Zuivelketen. Prestaties 2014 in perspectief. Rapport 2016-094. Wageningen, Wageningen Economic Research

Sanders, M. en J. Westerink, 2015. Op weg naar een natuurinclusieve duurzame landbouw. Wageningen, Alterra Wageningen UR

Schooten , H.A. van, N. van Eekeren, M.C. Hanegraaf, G.J.H.M. van der Burgt, M. de Visser (2006) Effect meerjarige toepassing groenbemester en organische mest op bodemkwaliteit bij continuteelt maïs: 2e rapport project Zorg voor Zand. Rapport 01. Animal Science Group, Wageningen. 40 p.

Schrödl, W., S. Krüger, T. Konstantinova-Müller, A.A. Shehata, R. Rulff, M. Krüger M., 2014. Possible effects of glyphosate on Mucorales abundance in the rumen of dairy cows in Germany. Curr Microbiol. 69(6):817-23.

Tsiafouli, M.A., E. Thébault, S.P. Sgardelis, P.C. de Ruiter, W.H. van der Putten, K. Birkhofer, L. Hemerik, F.T. de Vries, R.D. Bardgett, M.V. Brady, L. Bjornlund, H.B. Jørgensen, S. Christensen, T. D'Hertefeldt, S. Hotes, W.H.G. Hol, J. Frouz, M. Liiri, S.R. Mortimer, H. Setälä, J. Tzanopoulos, K. Uteseny, V. Pižl, J. Stary, V. Wolters, K. Hedlund (2015) Intensive agriculture reduces soil biodiversity across Europe. Global Change Biology 21: 973-985.

Vale, G.A., I.F. Grant (2004) Biological and chemical assays of pyrethroids in cattle dung. Bulletin of entomological research 94.03: 273-282.

Wardhaugh, K.G., B.C. Longstaff, M.J . Lacey (1998) Effects of residues of deltamethrin in cattle faeces on the development and survival of three species of dung-breeding insect. Australian Veterinary Journal. 1998 76(4):273-80.

Zijlstra, J., J.J. Poelarends, G. Migchels en F.A.N. van Alebeek, 2015. Routekaart Biodiversiteit Aanbevelingen voor de aanpak van biodiversiteit binnen de zuivelketen. Wageningen, Wageningen UR Livestock Research 


\section{Bijlage 1. Groslijst met indicatoren}

In onderstaande lijst staan de 98 indicatoren die door de auteurs zijn geselecteerd vanwege een veronderstelde mogelijke relatie met functionele agrobiodiversiteit. Ze zijn afkomstig uit de volgende databases:

- $\quad$ Bedrijveninformatienet (BIN) van Wageningen Economic Research;

- $\quad$ Landelijk Meetnet Mest en Mineralen (LMM), onderdeel van het BIN;

- Kringloopwijzer (KLW): gegevens ontleend aan Kringloopwijzer zoals die voorkomen in het BIN;

- Regelingsdata, waarin o.a. deelname aan en gegevens over Regeling Agrarisch Natuurbeheer (nummer regeling en areaal) zijn vastgelegd.

De inhoud van de databases is met name gericht op technische, financieel/economische en duurzaamheidsprestaties van bedrijven. Op dit moment is er weinig informatie over de ecologie op bedrijven voorhanden. In deze tabel staan alleen de variabelen die direct uit één van de genoemde databases komen. De variabelen die berekend zijn op basis van één of meer variabelen in onderstaande tabel staan er niet bij. Dit geldt bijvoorbeeld voor \% grasland, \% blijvend grasland, \% toepassing groenbemester na teelt voedergewas en milieubelastingspunten per ha.

De kleuren in onderstaande tabel zijn aangebracht om groepen indicatoren te kunnen onderscheiden. De indicatoren in de witte velden zijn direct of indirect (in de vorm van een verwante indicator) opgenomen in de lijst met indicatoren in tabel 3.2. Voor de indicatoren in de velden met overige kleuren is in bijlage 2 aangegeven waarom ze niet zijn opgenomen in tabel 3.2.

Voor het vaststellen van correlaties tussen geselecteerde indicatoren zijn aanvullende berekeningen gemaakt met enkele extra variabelen die in onderstaande tabel niet voorkomen. Tot deze groep extra variabelen behoorden o.a. totaal broeikasgassen (in CO2-equivalenten) per ha, ammoniakemissie (NH3) per ha en P-bodemoverschot per ha.

\begin{tabular}{|c|c|c|c|}
\hline Nr. & Omschrijving I ndicator & Eenheid & Opmerking \\
\hline 1. & Bedrijf neemt deel aan de Bedrijfseigen ammoniak emissie & $j \backslash n$ & \\
\hline 2. & Bedrijf neemt deel aan de Bedrijfsspecifieke excretie & $j \backslash n$ & \\
\hline 3. & Biologisch & $\mathrm{j} / \mathrm{n}$ & \\
\hline 4. & gebruik Kringloopwijzer & $\mathrm{j} / \mathrm{n}$ & \\
\hline 5. & Dierdagdosering melkkoeien (antibioticagebruik) & ddd & \\
\hline 6. & Weidegang ( 120 dagen, 6 uur) & $\mathrm{j} / \mathrm{n}$ & \\
\hline 7. & Overige beweiding & $\mathrm{j} / \mathrm{n}$ & \\
\hline 8. & Gemiddeld aantal melkkoeien & \# & \\
\hline 9. & Gemiddelde leeftijd afgevoerde melkkoeien & jaar & \\
\hline 10. & Percentage kalversterfte & $\%$ & \\
\hline 11. & Dieselverbruik & MJ & \\
\hline 12. & Aardgasverbruik & MJ & \\
\hline 13. & Elektriciteitsverbruik & kWh & \\
\hline 14. & Milieubelastingspunten gewasbescherming bodem & \# & \multirow{3}{*}{$\begin{array}{l}\text { Vanuit deze indicatoren wordt } \\
\text { totaal aantal } \\
\text { milieubelastingspunten } \\
\text { berekend }\end{array}$} \\
\hline 15. & $\begin{array}{l}\text { Milieubelastingspunten gewasbescherming } \\
\text { grondwater }\end{array}$ & \# & \\
\hline 16. & Milieubelastingspunten gewasbescherming water & \# & \\
\hline 17. & Aantal verkochte melkkoeien & \# & \\
\hline 18. & Botanisch beheer percelen & $\mathrm{j} / \mathrm{n}$ & \\
\hline 19. & Botanisch beheer randen & $\mathrm{j} / \mathrm{n}$ & \\
\hline 20. & Lid van agrarische natuurvereniging & $\mathrm{j} / \mathrm{n}$ & \\
\hline 21. & Onderhoud van landschapselementen & $\mathrm{j} / \mathrm{n}$ & \\
\hline
\end{tabular}




\begin{tabular}{|c|c|c|c|}
\hline Nr. & Omschrijving I ndicator & Eenheid & Opmerking \\
\hline 22. & Arbeidsjaareenheden & \# & \\
\hline 23. & Oppervlakte grasland & ha & \\
\hline 24. & Oppervlakte voedergewassen & ha & \\
\hline 25. & Oppervlakte cultuurgrond & ha & \\
\hline 26. & Oppervlakte groenbemesting & ha & $\begin{array}{l}\% \text { toepassing groenbemester na } \\
\text { teelt voedergewas wordt hieruit } \\
\text { berekend }\end{array}$ \\
\hline 27. & Oppervlakte natuurpacht & ha & \\
\hline 28. & Oppervlakte beregend & ha & \\
\hline 29. & Oppervlakte $\mathrm{Nx}$ beregend per jaar & ha & $\begin{array}{l}\text { sommige percelen worden } \\
\text { meerdere malen beregend }\end{array}$ \\
\hline 30. & Watergebruik & $\mathrm{m} 3$ & \\
\hline 31. & watergebruik bij beregening & m3 & \\
\hline 32. & Kunstmest gebruik & $\mathrm{kg} / \mathrm{ha}$ & \\
\hline 33. & Totaal arbeidsuren & uur & \\
\hline 34. & totaal arbeidsuren ondernemer & uur & \\
\hline 35. & Oppervlakte bos & ha & \\
\hline 36. & Oppervlakte blijvend bos & ha & \\
\hline 37. & Oppervlakte blijvend grasland & ha & $\begin{array}{l}\text { \% blijvend grasland wordt } \\
\text { hieruit berekend }\end{array}$ \\
\hline 38. & Oppervlakte tijdelijk grasland & ha & $\begin{array}{l}\text { \% grasland van de totale } \\
\text { bedrijfsoppervlakte wordt } \\
\text { berekend uit de som van } \\
\text { blijvend en tijdelijk grasland }\end{array}$ \\
\hline 39. & Bodemoverschot stikstof & $\mathbf{k g} / \mathbf{h a}$ & \\
\hline 40. & Stikstof benutting veestapel & $\%$ & \\
\hline 41. & Stikstof benutting mest & $\%$ & \\
\hline 42. & Stikstof benutting bodem & $\%$ & \\
\hline 43. & Stikstof benutting gewassen & $\%$ & \\
\hline 44. & Gasvormige verliezen stikstof & kg & \\
\hline 45. & Gemiddeld ruw eiwit gehalte in het rantsoen & $\mathrm{g} / \mathrm{kg}$ ds & \\
\hline 46. & Gemiddeld VEM gehalte in het rantsoen & vem/ $\mathrm{kg}$ ds & \\
\hline 47. & Percentage stikstof (eiwit) van eigen bedrijf & $\%$ & $\begin{array}{l}\% \text { voereiwit van eigen bedrijf } \\
\text { wordt hieruit berekend }\end{array}$ \\
\hline 48. & Percentage VEM van eigen bedrijf & $\%$ & \\
\hline 49. & Stikstof aanvoer per ton melk in voer & $\mathrm{kg}$ & \\
\hline 50. & Grasopbrengst drogestof & $\mathrm{kg} / \mathrm{ha}$ & \\
\hline 51. & Grasopbrengst KVEM & $\mathrm{kg} / \mathrm{ha}$ & \\
\hline 52. & Grasopbrengst Stikstof & $\mathrm{kg} / \mathrm{ha}$ & \\
\hline 53. & Snijmaïsopbrengst drogestof & $\mathrm{kg} / \mathrm{ha}$ & \\
\hline 54. & Snijmaïsopbrengst KVEM & $\mathrm{kg} / \mathrm{ha}$ & \\
\hline 55. & Snijmaïsopbrengst Stikstof & $\mathrm{kg} / \mathrm{ha}$ & \\
\hline 56. & Aandeel drijfmest melkkoeien & $\%$ & \\
\hline 57. & Aandeel drijfmest kalveren & $\%$ & \\
\hline 58. & Aandeel drijfmest pinken & $\%$ & \\
\hline 59. & Percentage grasland & $\%$ & \\
\hline 60. & Percentage snijmaïs & $\%$ & \\
\hline 61. & Percentage overige gewassen & $\%$ & \\
\hline 62. & Fosfaat GVE per ha alle graasdieren & GVE/ha & \\
\hline
\end{tabular}




\begin{tabular}{|c|c|c|c|}
\hline Nr. & Omschrijving I ndicator & Eenheid & Opmerking \\
\hline 63. & Meetmelk productie totaal & $\mathrm{kg}$ & \\
\hline 64. & Meetmelk productie per ha voedergewassen & $\mathrm{kg} / \mathrm{ha}$ & \\
\hline 65. & Meetmelk productie per melkkoe & $\mathrm{kg}$ & \\
\hline 66. & Maaipercentage & $\%$ & \\
\hline 67. & Percentage weide uren mei $\mathrm{t} / \mathrm{m}$ juni melkkoeien & $\%$ & \\
\hline 68. & Percentage weide uren juli $\mathrm{t} / \mathrm{m}$ augustus melkkoeien & $\%$ & \\
\hline 69. & Percentage weide uren september $\mathrm{t} / \mathrm{m}$ oktober melkkoeien & $\%$ & \\
\hline 70. & Percentage weide uren september $\mathrm{t} / \mathrm{m}$ oktober kalveren & $\%$ & \\
\hline 71. & Percentage weide uren september $\mathrm{t} / \mathrm{m}$ oktober pinken & $\%$ & \\
\hline 72. & Broeikasgasemissie $\mathrm{CH} 4$ in $\mathrm{CO} 2$ equivalenten & CO2-eq & \\
\hline 73. & Broeikasgasemissie $\mathrm{N} 2 \mathrm{O}$ in $\mathrm{CO} 2$ equivalenten & CO2-eq & \\
\hline 74. & $\begin{array}{l}\text { Broeikasgasemissie } \mathrm{CO} 2 \text { (incl. } \mathrm{CH} 4 \text { en } \mathrm{N} 2 \mathrm{O} \text { ) in } \mathrm{CO} 2 \\
\text { equivalenten }\end{array}$ & CO2-eq & \\
\hline 75. & leeftijd voor scheuren grasland & jaar & \\
\hline 76. & aandeel grasland gescheurd & $\%$ & \\
\hline 77. & Gras na scheuren & $\mathrm{j} / \mathrm{n}$ & \\
\hline 78. & Maïs na scheuren & $\mathrm{j} / \mathrm{n}$ & \\
\hline 79. & Geen vervolggewas na scheuren & $\mathrm{j} / \mathrm{n}$ & \\
\hline 80. & Aandeel grasland doorgezaaid & $\%$ & \\
\hline 81. & Stikstof behoeftige gewassen na scheuren & $\mathrm{j} / \mathrm{n}$ & \\
\hline 82. & Gewasbescherming werkzame stof per $100 \mathrm{~kg}$ melk & $\mathrm{kg} \backslash 100 \mathrm{~kg}$ melk & \\
\hline 83. & arbeidsuren per $100 \mathrm{~kg}$ melk & uur/kg & \\
\hline 84. & Diesel verbruik per $100 \mathrm{~kg}$ melk & MJ / kg & \\
\hline 85. & Aardgas verbruik per $100 \mathrm{~kg}$ melk & $\mathrm{MJ} / \mathrm{kg}$ & \\
\hline 86. & Elektriciteitsverbruik per $100 \mathrm{~kg}$ melk & $\mathrm{kWh} / \mathrm{kg}$ & \\
\hline 87. & Waterverbruik per $100 \mathrm{~kg}$ melk & $\mathrm{m} 3 / \mathrm{kg}$ & \\
\hline 88. & Methaan emissie in CO2-eq per $100 \mathrm{~kg}$ melk & $\begin{array}{l}\text { kg CO2-eq } \backslash 100 \\
\text { kg melk }\end{array}$ & \\
\hline 89. & Lachgas emissie in CO2-eq per $100 \mathrm{~kg}$ melk & $\begin{array}{l}\text { kg CO2-eq } \backslash 100 \\
\text { kg melk }\end{array}$ & \\
\hline 90. & Totaal CO2 emissie (incl. $\mathrm{CH} 4$ en N2O) per $100 \mathrm{~kg}$ melk & $\begin{array}{l}\text { kg CO2-eq } \backslash 100 \\
\text { kg melk }\end{array}$ & \\
\hline 91. & Oppervlakte natuurgrond & ha & \\
\hline 92. & Betalingen natuurgrond & euro & \\
\hline 93. & Deelname aan natuurbeheer & $j \backslash n$ & \\
\hline 94. & Percentage van het oppervlak klei & $\%$ & \\
\hline 95. & Percentage van het oppervlak veen & $\%$ & \\
\hline 96. & Percentage van het oppervlak zand & $\%$ & \\
\hline 97. & Diergezondheidskosten per koe & euro & \\
\hline 98. & Gewaskosten per hectare & euro & \\
\hline
\end{tabular}




\section{Bijlage 2. Argumenten waarom indicatoren niet zijn meegenomen als KPI}

In onderstaande tabel is voor groepen indicatoren uit bijlage 1 aangegeven wat de redenen zijn voor het niet opnemen van de indicatoren in de selecte groep indicatoren die in tabel 3.2 is weergegeven. De kleuren in onderstaande tabel komen overeen met de arceringen van de bijbehorende indicatoren in bijlage 1.

\begin{tabular}{|c|c|}
\hline Thema & $\begin{array}{l}\text { Toelichting op argumenten waarom indicatoren niet zijn } \\
\text { opgenomen }\end{array}$ \\
\hline $\begin{array}{l}\text { Agrarisch natuur- en } \\
\text { landschapsbeheer en bosbeheer }\end{array}$ & $\begin{array}{l}\text { Dit rapport gaat over pijler } 1 \text { uit het conceptueel kader van Erisman } \\
\text { e.a. (2014): functionele agrobiodiversiteit. Deze indicatoren passen } \\
\text { bij de overige pijlers uit het conceptueel kader. }\end{array}$ \\
\hline $\begin{array}{l}\text { CO2 / N2O / energieverbruik / } \\
\text { Fosfaat }\end{array}$ & $\begin{array}{l}\text { Uit de correlatiematrix blijkt dat deze indicatoren sterk gerelateerd } \\
\text { zijn aan NH3 emissie per ha, N overschot per ha en \% eiwit van } \\
\text { eigen land. Bij de wens om een zo beperkt aantal KPI's te gebruiken } \\
\text { is het niet nodig deze indicatoren ook te gebruiken als KPI. }\end{array}$ \\
\hline Arbeidsefficientie, bedrijfsomvang & $\begin{array}{l}\text { Van bedrijfsgrootte en arbeidsefficiëntie wordt geen directe relatie } \\
\text { verwacht met functionele agrobiodiversiteit. Daarom zijn ze niet als } \\
\text { indicator meegenomen. }\end{array}$ \\
\hline Diergezond(heidskosten) & $\begin{array}{l}\text { Van diergezondheid(skosten) wordt geen directe relatie verwacht } \\
\text { met functionele agrobiodiversiteit. Daarom zijn ze niet als indicator } \\
\text { meegenomen. Indirect zijn er wel interacties denkbaar. Om de } \\
\text { relatie directer te maken, is gekozen om de indicator 'Gebruik van } \\
\text { ontwormings- en vliegenbestrijdingsmiddelen' toe te voegen. } \\
\text { Gebruik van deze middelen heeft een negatief effect op het } \\
\text { bodemleven. }\end{array}$ \\
\hline Watergebruik \& Mais & $\begin{array}{l}\text { Watergebruik/beregenen en teelt mais blijken sterk aan elkaar } \\
\text { verbonden. Via \% (blijvend) grasland is indirect het aandeel mais } \\
\text { ook duidelijk, want overige teelten van voedergewassen komt } \\
\text { relatief weinig voor. Hiermee is aantal indicatoren beperkt. }\end{array}$ \\
\hline Beweiding & $\begin{array}{l}\text { Indicatoren rond beweiding zijn niet opgenomen als KPI. Er zijn wel } \\
\text { aanwijzingen dat weidegang een positief effect heeft op } \\
\text { biodiversiteit (Van Eekeren et al., 2015). In de factoranalyse kwam } \\
\text { weidegang niet naar voren als hoofdfactor en in de systeemanalyse } \\
\text { is er vanuit gegaan dat eventuele weidegangsindicatoren overlap } \\
\text { zullen vertonen met \% grasland, \% blijvend grasland, N- } \\
\text { bodemoverschot en \% voereiwit van eigen bedrijf. }\end{array}$ \\
\hline Stikstofbenutting / bemesting & $\begin{array}{l}\text { De mix van deze indicatoren, die gerelateerd zijn aan } \\
\text { stikstofbenutting en - bemesting, leiden uiteindelijk tot twee } \\
\text { belangrijke indicatoren die een maat zijn van de stikstofverliezen via } \\
\text { de bodem en water ( } \mathrm{N} \text {-overschot / ha) en lucht ( } \mathrm{NH3} \text { emissie/ha). }\end{array}$ \\
\hline Bedrijfskenmerken & $\begin{array}{l}\text { Hier gaat het om bedrijfskenmerken als grondsoort en al dan niet } \\
\text { biologisch. Grondsoort is een gegeven waar de ondernemer niets } \\
\text { aan kan veranderen. Wel / niet biologisch is een keuze die invloed } \\
\text { heeft op bepaalde indicatoren. Onderscheidend is bijvoorbeeld het } \\
\text { percentage drijfmest, benutting van de mest, kunstmestgebruik, } \\
\text { bodemoverschot en weidegang. Echter, zowel biologische als } \\
\text { gangbare melkveehouders kunnen bijdragen aan functionele } \\
\text { agrobiodiversiteit. Het onderscheid is daarom niet meegenomen in } \\
\text { het lijstje met geselecteerde indicatoren. Daarnaast valt hieronder } \\
\text { ook een 'restcategorie' die betrekking heeft op het gebruik } \\
\text { Kringloopwijzer en BEA/BEX. }\end{array}$ \\
\hline Grondgebruik & $\begin{array}{l}\text { Deze bedrijfskenmerken zijn gerelateerd aan grondgebruik en die } \\
\text { zijn direct / indirect gerelateerd aan de geselecteerde indicatoren. Er } \\
\text { is gekozen voor een drietal indicatoren die het grondgebruik }\end{array}$ \\
\hline
\end{tabular}




\begin{tabular}{|l|l|}
\hline & $\begin{array}{l}\text { kenmerken: \% grasland, \% blijvend grasland, indicator } \\
\text { grondbewerking bouwland/voedergewassen en \% groenbemester na } \\
\text { teelt voedergewas. Daarnaast zijn er nog indicatoren geselecteerd } \\
\text { die ingaan op de samenstelling van de bodem, namelijk organische } \\
\text { stofbalans bouwland/voedergewassen en \% organische stof } \\
\text { grasland/bouwland. }\end{array}$ \\
\hline Gewasbeschermingsmiddelen & $\begin{array}{l}\text { Dit bedrijfskenmerk is via de indicator milieubelastingspunten per ha } \\
\text { afgedekt. }\end{array}$ \\
\hline Percentage VEM van eigen bedrijf & $\begin{array}{l}\text { Het percentage VEM van eigen bedrijf is met name op bedrijven met } \\
\text { grotendeels grasland sterk gerelateerd aan het \% voereiwit van } \\
\text { eigen bedrijf en op die manier meegenomen in de indicatoren. }\end{array}$ \\
\hline
\end{tabular}




\section{Bijlage 3. Correlatiematrix per grondsoort}

\begin{tabular}{|c|c|c|c|c|c|c|c|c|c|c|c|c|c|c|c|}
\hline \multicolumn{16}{|l|}{ Correlaties voor grondsoort zand } \\
\hline Indicatoren & \begin{tabular}{|c|} 
\\
Totale \\
ammoni- \\
akemissie \\
per \\
hectare
\end{tabular} & $\begin{array}{c}\text { Percenta- } \\
\text { ge } \\
\text { grasland } \\
\text { van totaal } \\
\text { areaal } \\
\text { cultuur- } \\
\text { grond }\end{array}$ & \begin{tabular}{|c|} 
Meetmelk \\
productie \\
per \\
hectare
\end{tabular} & \begin{tabular}{|c|} 
Percenta- \\
ge stikstof \\
(eiwit) van \\
eigen \\
bedrijf
\end{tabular} & $\begin{array}{c}\text { Aandeel } \\
\text { organi- } \\
\text { sche stof } \\
\text { bouwland }\end{array}$ & $\begin{array}{c}\text { Aandeel } \\
\text { organi- } \\
\text { sche stof } \\
\text { grasland }\end{array}$ & $\begin{array}{c}\text { Percenta- } \\
\text { ge blijvend } \\
\text { grasland } \\
\text { van } \\
\text { grasland- } \\
\text { areaal }\end{array}$ & $\begin{array}{l}\text { Percenta- } \\
\text { ge } \\
\text { groenbe- } \\
\text { mesting }\end{array}$ & \begin{tabular}{|c|} 
Milieube- \\
lastings- \\
punten \\
gewasbe- \\
scher- \\
ming per \\
hectare
\end{tabular} & $\begin{array}{c}\text { leeftijd } \\
\text { voor } \\
\text { scheuren } \\
\text { grasland }\end{array}$ & $\mid \begin{array}{c}\text { Betalin- } \\
\text { gen natuur } \\
\text { grond }\end{array}$ & $\begin{array}{c}\text { Bodemove } \\
\text { rschot } \\
\text { stikstof }\end{array}$ & $\begin{array}{c}\text { Totaal } \\
\text { CO2 } \\
\text { emissie } \\
\text { (incl. } \mathrm{CH} 4 \\
\text { en } \mathrm{N} 2 \mathrm{O} \text { ) } \\
\text { per } \\
\text { hectare }\end{array}$ & $\begin{array}{c}\text { Kool- } \\
\text { dioxide } \\
\text { emissie } \\
\text { per } \\
\text { hectare }\end{array}$ & $\begin{array}{c}\text { Lachgas } \\
\text { emissie in } \\
\text { CO2-eq } \\
\text { per } \\
\text { hectare }\end{array}$ \\
\hline Percentage grasland van totaal areaal cultuurgrond & 0.078 & & & & & & & & & & & & & & \\
\hline Meetmelkproductie per hectare & $.600^{\star *}$ & $-.319 * \star$ & & & & & & & & & & & & & \\
\hline Percentage stikstof (eiwit) van eigen bedrijf & $-.326^{\star *}$ & $.169 * *$ & $-.640^{\star \star}$ & & & & & & & & & & & & \\
\hline Aandeel organische stof bouwland & -0.068 & $.135^{*}$ & $-.181^{\star \star}$ & $.267^{\star *}$ & & & & & & & & & & & \\
\hline Aandeel organische stof grasland & $-.207 * *$ & 0.117 & $-.228^{* *}$ & $.276^{\star \star}$ & $.597^{\star \star}$ & & & & & & & & & & \\
\hline Percentage blijvend grasland van graslandareaal & -0.110 & $.338 * \star$ & $-.331^{\star \star}$ & $.291^{\star \star}$ & 0.083 & 0.069 & & & & & & & & & \\
\hline Percentage groenbemesting & -0.031 & 0.006 & 0.067 & -0.034 & -0.051 & -0.003 & 0.076 & & & & & & & & \\
\hline Milieubelastingspunten gewasbescherming per hectare & -0.011 & $-.195^{\star *}$ & $.106^{*}$ & -0.007 & 0.017 & 0.018 & $-.235^{\star *}$ & 0.095 & & & & & & & \\
\hline leeftijd voor scheuren grasland & -0.015 & 0.029 & -0.007 & 0.061 & 0.050 & 0.018 & 0.061 & 0.060 & 0.041 & & & & & & \\
\hline Betalingen natuurgrond & -0.082 & $.129 *$ & $-.143^{* \star}$ & $.168^{\star \star}$ & 0.009 & 0.028 & 0.017 & 0.025 & -0.054 & 0.023 & & & & & \\
\hline Bodemoverschot stikstof & $.289 \star \star$ & $-.157 \star \star$ & $.364^{\star \star}$ & $-.675^{\star \star}$ & -0.073 & -0.064 & -0.083 & $.193^{\star \star}$ & 0.026 & 0.022 & $-.181^{\star \star}$ & & & & \\
\hline Totaal CO2 emissie (incl. CH4 en N2O) per hectare & $.609^{\star \star}$ & $-.291 * \star$ & $.926^{\star \star}$ & $-.648^{\star *}$ & $-.129^{*}$ & $-.186^{* *}$ & $-.283^{\star *}$ & 0.050 & 0.008 & -0.034 & $-.182^{\star \star}$ & $.437^{\star \star}$ & & & \\
\hline Kooldioxide emissie per hectare & $.573^{\star \star}$ & $-.278^{* *}$ & $.833^{\star \star}$ & $-.626^{\star *}$ & $-.129^{*}$ & $-.190^{* *}$ & $-.215^{\star *}$ & 0.061 & -0.003 & -0.032 & $-.163^{* *}$ & $.471^{\star \star}$ & $.953^{\star *}$ & & \\
\hline Lachgas emissie in CO2-eq per hectare & $.172^{\star \star}$ & -0.059 & $.293^{\star \star}$ & $-.137^{*}$ & $.213^{\star \star}$ & $.223^{\star \star}$ & 0.079 & $.108^{*}$ & -0.073 & 0.043 & $-.107^{*}$ & $.461^{\star \star}$ & $.445^{\star \star}$ & $.389 * \star$ & \\
\hline Methaan emissie in CO2-eq per hectare & $.609^{\star \star *}$ & $-.292 * *$ & $.951^{\star \star}$ & $-.643^{* *}$ & $-.155^{*}$ & $-.211^{* *}$ & $-.342^{\star *}$ & 0.027 & 0.025 & -0.041 & $-.183^{\star \star}$ & $.347^{\star \star}$ & $.971^{\star \star}$ & $.862^{\star \star}$ & $.353^{\star \star}$ \\
\hline
\end{tabular}

Methaan emissie in CO2-eq per hectare

** Correlatie is significant $p<0.01$ level (2-zijdig).

${ }^{\star}$ Correlatie is significant $p<0.05$ level (2-zijdig). 


\section{Correlaties voor arondsoort klei}

Indicatoren

Totale

areaal

per
cultuur-

Percentage grasland van totaal areaal cultuurgrond

Meetmelkproductie per hectare

Percentage stikstof (eiwit) van eigen bedrijf

Aandeel organische stof bouwland

Aandeel organische stof grasland

Percentage blijvend grasland van graslandareaal

Percentage groenbemesting

Milieubelastings punten gewasbescherming per hectare

leeftijd voor scheuren grasland

Betalingen natuurgrond

Bodemoverschot stikstof

Totaal CO2 emissie (incl. CH4 en N2O) per hectare

Kooldioxide emissie per hectare

Lachgas emissie in $\mathrm{CO}$-eq per hectare

Methaan emissie in $\mathrm{CO}$-eq per hectare

${ }^{\star *}$ Correlatie is significant $p<0.01$ level (2-zijdig).

${ }^{\star}$ Correlatie is significant $p<0.05$ level (2-zijdig).

0.047

(n)

\begin{tabular}{r|r}
$.433^{\star \star}$ & $-.296^{\star *}$ \\
\hline$-.275^{*}$ & $.213 *$ \\
\hline
\end{tabular}

Percenta-

grasland Percenta- gewasbe- leeftijd

hectare bedrijf bouwland grasland

Betalin- Bodemove (incl. $\mathrm{CH} 4$ dioxide emissie in

areaal mesting

\begin{tabular}{ll|l|l|l} 
& &
\end{tabular}

\begin{tabular}{|r|r|r|r|}
\hline-0.008 & 0.168 & 0.018 & 0.190 \\
\hline
\end{tabular}

\begin{tabular}{|r|r|r|r|r|r|}
\hline-0.008 & 0.168 & 0.018 & 0.190 & & \\
\hline 0.054 & $.387^{* \star}$ & -0.177 & $.242^{*}$ & $.395^{* \star}$ & \\
\hline 0.031 & $-.170^{* *}$ & 0.076 & $.272^{* \star}$ & $.245^{*}$ \\
\hline
\end{tabular}

\begin{tabular}{r|r|r|r|r|r|}
\hline 0.031 & $-192 *$ & -.170 & 0.076 & $.272^{* *}$ & .245 \\
\hline-0.027 & $-.207 *$ & .146 & $-.214^{*}$ & -0.083 & -0.214 \\
\hline
\end{tabular}

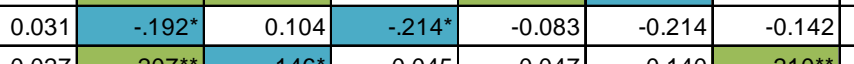

\begin{tabular}{|r|r|r|r|r|r|r|r|r|}
0.031 & $-.192^{\star}$ & 0.104 & $-.214^{*}$ & -0.083 & -0.214 & -0.142 & & \\
\hline-0.027 & $-.207^{\star \star}$ & $.146^{*}$ & -0.045 & -0.047 & -0.140 & $-.210^{* \star}$ & -0.043 & \\
\hline $.176^{*}$ & 0.087 & -0.002 & -0.006 & -0.173 & -0.086 & 0.069 & 0.010 & -0.035 \\
\hline 0.003 & 0.05 & -0.060 & $.62 *$ & 0.031 & 0.090 & 0.023 & 0.061 & -0.032 \\
\hline
\end{tabular}

\begin{tabular}{|r|r|r|r|r|r|r|r|r|r|}
\hline $.176^{*}$ & 0.087 & -0.002 & -0.006 & -0.173 & -0.086 & 0.069 & 0.010 & -0.035 & \\
\hline 0.003 & 0.056 & -0.060 & $.162^{*}$ & 0.031 & 0.090 & 0.023 & 0.061 & -0.032 & 0.097 \\
\hline
\end{tabular}

\begin{tabular}{r|r|r|r|r|r|}
$.331^{\star \star}$ & $-.192^{\star}$ & $.491^{\star \star}$ & $-.711^{\star \star}$ & -0.216 & $-.344^{\star \star}$ \\
\hline $.472^{\star \star}$ & $-.182^{\star \star}$ & $.887^{\star \star}$ & $-.600^{\star \star}$ & -0.060 & -0.151 \\
\hline $.427^{* *}$ & $-.208 *$ & $.851^{\star *}$ & $-.57{ }^{*}$ & -0.017 & -.197 \\
\hline
\end{tabular}

\begin{tabular}{|c|c|c|c|c|c|}
\hline & & & & & \\
\hline $427 * \star$ & $-208^{\star \star}$ & $.851^{\star \star}$ & $-.579 * *$ & -0.017 & \\
\hline $232 * \star$ & 0.021 & $.459^{* \star}$ & $-.238 * *$ & 0.069 & \\
\hline $482^{\star \star}$ & $-.170^{\star \star \star}$ & $.882^{* \star}$ & $-.588^{* \star}$ & -0.108 & \\
\hline
\end{tabular}

\begin{tabular}{r|r|r|r|}
$-.344^{\star *}$ & 0.006 & -0.019 & 0.09 \\
\hline-.151 & -0.079 & -0.082 & 0.10 \\
\hline $.197^{*}$ & -0.055 & -0.067 & 0.11 \\
\hline 0.071 & 0.019 & $-.305^{\star *}$ & 0.09 \\
\hline 0.119 & -0.105 & -0.051 & 0.08 \\
\hline
\end{tabular}

\begin{tabular}{r|r|r|r}
\hline 0.094 & 0.076 & -0.079 & \\
\hline 0.104 & 0.010 & -0.039 & .5 \\
\hline 0.113 & 0.039 & -0.069 & .509 \\
\hline 0.091 & -0.036 & 0.025 & .548 \\
\hline 0.086 & -0.009 & -0.019 & .489 \\
\hline
\end{tabular}

$-.305^{\star \star}$

\begin{tabular}{l|l|}
0.091 & -0.036 \\
\hline 0.086 & -0.009 \\
\hline
\end{tabular}

0.025
-0.019

\begin{tabular}{|c|c|c|c|}
\hline $\begin{array}{c}\text { Bodemove } \\
\text { rschot } \\
\text { stikstof }\end{array}$ & \begin{tabular}{|c|} 
Totaal \\
CO2 \\
emissie \\
(incl. $\mathrm{CH} 4$ \\
en $\mathrm{N} 2 \mathrm{O}$ ) \\
per \\
hectare
\end{tabular} & $\begin{array}{c}\text { Kool- } \\
\text { dioxide } \\
\text { emissie } \\
\text { per } \\
\text { hectare }\end{array}$ & $\begin{array}{c}\text { Lachgas } \\
\text { emissie in } \\
\text { CO2-eq } \\
\text { per } \\
\text { hectare }\end{array}$ \\
\hline & & & \\
\hline & & & \\
\hline & & & \\
\hline & & & \\
\hline & & & \\
\hline & & & \\
\hline & & & \\
\hline & & & \\
\hline & & & \\
\hline & & & \\
\hline & & & \\
\hline $.540^{* *}$ & & & \\
\hline $.509^{\star *}$ & $.957^{\star \star *}$ & & \\
\hline $.548^{\star \star}$ & $.672^{* *}$ & $.570^{\star \star}$ & \\
\hline $.489^{* *}$ & $.972 * *$ & $.870 * \star$ & $.631^{* *}$ \\
\hline
\end{tabular}




\section{Correlaties voor grondsoort veen}

Percentage grasland van totaal areaal cultuurgrond

Meetmelkproductie per hectare

Percentage stikstof (eiwit) van eigen bedrijf

Aandeel organische stof bouwland

Aandeel organische stof grasland

Percentage blijvend grasland van graslandareaal

Milieubelastingspunten gewasbescherming per hectare

leeftijd voor scheuren grasland

Betalingen natuurgrond

Bodemoverschot stikstof

Totaal $\mathrm{CO} 2$ emissie (incl. $\mathrm{CH} 4$ en N2O) per hectare

Kooldioxide emissie per hectare

Lachgas emissie in $\mathrm{CO} 2-$ eq per hectare

Methaan emissie in CO2-eq per hectare

** Correlatie is significant $p<0.01$ level (2-zijdig).

* Correlatie is significant $p<0.05$ level ( 2 -zijdig). 


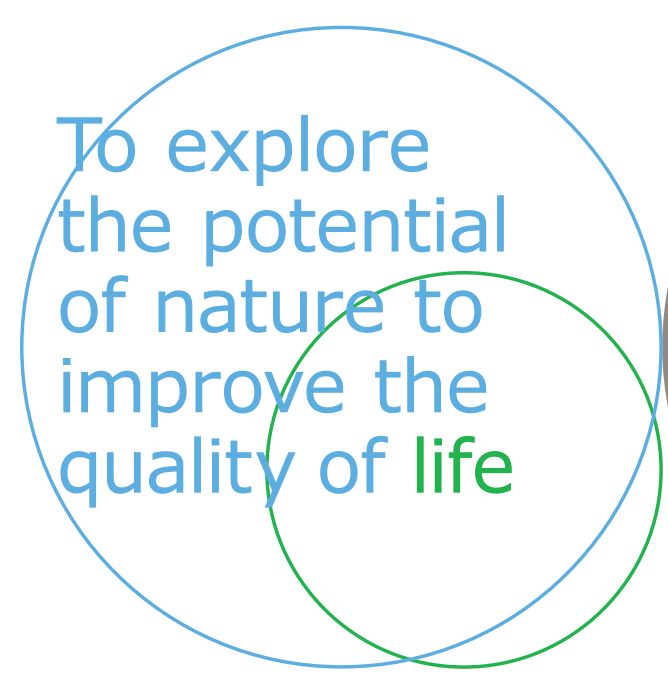

Wageningen Livestock Research Postbus 338

$6700 \mathrm{AH}$ Wageningen

T 0317483953

E info.livestockresearch@wur.nl www.wur.nl/livestock-research

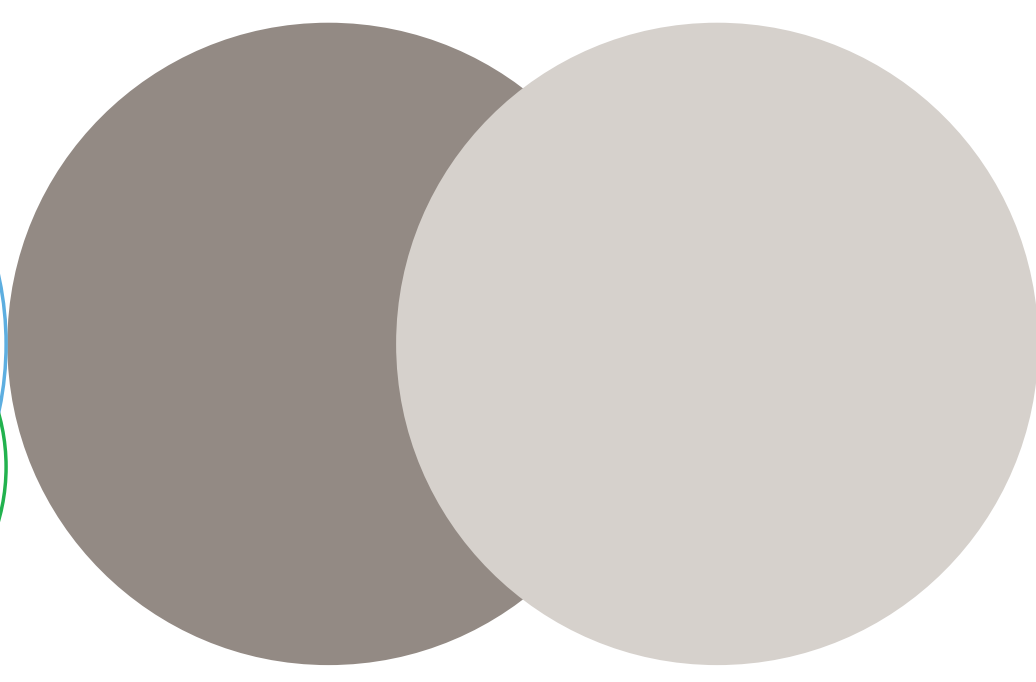

Louis Bolk Instituut

Hoofdstraat 24

3972 LA Driebergen

T 0343523860

E info@louisbolk.nl

www.louisbolk.nl 